\title{
Geographies of Power: The Tunisian Civic Order, Jurisdictional Politics, and Imperial Rivalry in the Mediterranean, 1881-1935
}

\section{Citation}

Lewis, Mary Dewhurst. Geographies of power: The Tunisian civic order, jurisdictional politics, and imperial rivalry in the Mediterranean, 1881-1935. Journal of Modern History 80(4): 791-830.

\section{Published Version}

http://dx.doi.org/10.1086/591111

\section{Permanent link}

http://nrs.harvard.edu/urn-3:HUL.InstRepos:2665770

\section{Terms of Use}

This article was downloaded from Harvard University's DASH repository, and is made available under the terms and conditions applicable to Other Posted Material, as set forth at http:// nrs.harvard.edu/urn-3:HUL.InstRepos:dash.current.terms-of-use\#LAA

\section{Share Your Story}

The Harvard community has made this article openly available.

Please share how this access benefits you. Submit a story.

Accessibility 


\title{
Geographies of Power: The Tunisian Civic Order, Jurisdictional Politics, and Imperial Rivalry in the Mediterranean, 1881-1935*
}

\author{
Mary Dewhurst Lewis \\ Harvard University
}

In a letter dated November 1883, Paul Cambon, the resident minister of France's protectorate of Tunisia, confided to his wife that "if the Capitulations aren't suppressed, we'll find ourselves backed into a corner [nous voilà acculés]." ${ }^{1}$ These Capitulations-similar to legal arrangements prevailing in the Ottoman Empire, of which Tunisia had been a semiautonomous province until the French conquest in 1881-granted a number of legal immunities to foreign nationals and holders of foreign "patents of protection.". Why would the senior administrator of France's new protectorate worry about the legal status of nationals belonging to the rival states it had outmaneuvered to win Tunisia? After all, France had just signed a treaty promising to protect the Tunisian bey's dynasty in exchange for the right to "occupy all areas deemed necessary for the reestablishment of order and security of both borders and

\footnotetext{
* Research for this article was made possible by the Harvard University Clark/ Cooke Funds and a Junior Faculty Research grant from the Harvard Academy for International and Area Studies. The Centre d'Études Maghrébines à Tunis, and especially Jim Miller and Riadh Saadaoui, facilitated research in Tunis. Hinda Amar of the Tunisian National Archives was very helpful in locating documents. The central themes of this article were first presented at the Society for French Historical Studies annual meeting in 2004 (Paris) and subsequently developed in presentations to the graduate seminar led by Emmanuelle Saada at the École des Hautes Études en Sciences Sociales in Paris, the International History Seminar at Harvard University, the Johns Hopkins University History Seminar, the American Historical Association meeting in Atlanta in January 2007, and the Society for French Historical Studies meeting in Houston in March 2007. I thank the participants at each of these venues for their excellent feedback. I also wish to thank Iliana Montauk for her research assistance and insightful reflections on this project, as well as Julia Clancy-Smith, Alice Conklin, Frederick Cooper, Peter Dizikes, Alison Frank, Will Hanley, Charles Maier, Mark Mazower, Susan Miller, Emma Rothschild, Tara Zahra, and the anonymous reviewers for their detailed comments on earlier versions of the article.

${ }^{1}$ Letter to Mme Paul Cambon, La Marsa, November 30, 1883, in Paul Cambon, Correspondance, 1870-1924, vol. 1, 1870-1898 (Paris, 1940), 203.

${ }^{2}$ Capitulations were also prevalent in other Muslim states, such as Morocco, and in states where European merchants demanded special treatment, such as China.
}

The Journal of Modern History 80 (December 2008): 791-830 (C) 2008 by The University of Chicago. 0022-2801/2008/8004-0002 $\$ 10.00$ All rights reserved. 
coastline." 3 The treaty seemed to settle the question of which European state controlled Tunisia. Instead, I will argue, it marked the beginning of a new phase of imperial rivalry, as European powers found novel ways to compete for influence in the protectorate by exploiting fissures in the rule of law. In turn, individuals in Tunisia sought to exercise power over their everyday lives by doing the same, playing the protectorate's multiple jurisdictions off each other to settle quotidian social conflict. ${ }^{4}$ These two forms of power struggle did not merely overlap; they were intertwined. Local disputes-between the administration and taxpayers, creditors and debtors, or husbands and wives, among others - exposed and exacerbated divisions between European states.

By the eve of the First World War, French authorities still felt "backed into a corner," albeit not in exactly the ways Cambon had feared. In part this was because, in navigating the geographies of power that protectorate rule had helped to introduce, France instituted reforms that endeavored to curtail the very Tunisian sovereignty it originally had claimed to protect. This is not to say that French rule over Tunisia began benevolently and became more sinister-French intentions were never altruistic. Rather, the present article explains why French colonial governance in Tunisia shifted in nature, from an insistence that Tunisia was a "foreign" territory under the sovereignty of the bey to a claim that France shared in the bey's sovereignty and that the territory itself was in some way "French." It accounts for this transformation by reconstructing the connection between international relations in the Mediterranean basin and the social uses of the law in Tunisia during the first fifty years of protectorate rule..$^{5}$

${ }^{3}$ Traité entre le gouvernement de la République française et le Bey de Tunis, May 12, 1881, in Ministère des Affaires Étrangères, Documents Diplomatiques: Affaires de Tunisie; Supplément, Avril-Mai 1881 (Paris, 1881), 38-40.

${ }^{4}$ Scholars have sometimes noted the place of Tunisia in Franco-Italian foreign policy, but they have not connected those foreign-policy concerns to everyday life in the protectorate as I propose to do here. See the pioneering work of William I. Shorrock, "The Tunisian Question in French Policy toward Italy, 1881-1940," International Journal of African Historical Studies 16, no. 4 (1983): 631-51. For the escalation of this rivalry, see, in addition to the above, Juliette Bessis, La Méditerranée fasciste: L'Italie mussolinienne et la Tunisie (Paris, 1981).

${ }^{5}$ For an important account that highlights the social uses of the law in the precolonial period, see esp. Julia Clancy-Smith, "Marginality and Migration: Europe's Social Outcasts in Pre-colonial Tunisia, 1830-81," in Outside In: On the Margins of the Modern Middle East, ed. Eugene Rogan (London, 2002), 149-82, and "Women, Gender, and Migration along a Mediterranean Frontier: Pre-colonial Tunisia, c. 18151870," Gender and History 17, no. 1 (April 2005): 62-92. Clancy-Smith's forthcoming book, Mediterranean Odysseys: Migrants and Migrations in Nineteenth-Century North Africa, c. 1800-1881 (Berkeley, forthcoming), will develop these themes. I would like to thank Professor Clancy-Smith for alerting me to this work in progress and for granting me special permission to see chap. 6 in advance of publication. 
When Ottoman rulers first entered into capitulatory agreements in the late Middle Ages, they regarded them as beneficial to the Ottoman state, for the legal immunities facilitated international trade and relieved the sultan of responsibility for protecting foreign subjects. Granting Capitulations unilaterally, the sultans understood these privileges (imtiyāza $\bar{a} t$ ) to be revocable acts of generosity, not permanent cessions of sovereign rights. During the nineteenth century, however, Western powers increasingly interpreted the personal privileges accorded by the Capitulations as justifying blanket extraterritorial rights. As a result, what once had been mutually beneficial legal arrangements began to compromise the sovereignty of the sultan and his regents. ${ }^{6}$ In Tunisia, the Husaynid dynasty and European powers clashed from the midnineteenth century over similar issues. As in other Ottoman lands, foreign consuls based in Tunis increasingly extended their purview to all nationals of the state they represented, thereby challenging the Husaynid beys' longstanding practice of offering individual protection to those hoping to avoid their consul's authority and bringing to a close a long history of their dependence on beylical power. ${ }^{7}$ After assuming leadership of France's protectorate

${ }^{6}$ P. J. Bearman et al., eds., Encyclopedia of Islam, 2nd ed., 12 vols. (Leiden, 1960-2005), s.v. "imtiyāzāt" (by H. Inalcik et al.), online ed.; Feroz Ahmad, "Ottoman Perceptions of the Capitulations, 1800-1914," Journal of Islamic Studies 11, no. 1 (2000): 1-20; Donald Quataert, The Ottoman Empire, 1700-1922, 2nd ed. (Cambridge, 2005), 79; Christian Windler, La diplomatie comme expérience de l'autre: Consuls Français au Maghreb (1700-1840) (Geneva, 2002), esp. 220-23. For examples of how French consuls endeavored to cast personal privileges accorded by the Tunisian bey as extraterritorial rights extending to all French nationals in the Regency, see Christian Windler, "Representing a State in a Segmentary Society: French Consuls in Tunis from the Ancien Régime to the Restoration," Journal of Modern History 73 (June 2001): 233-74. A similar trend is noticeable in Morocco. See Susan Miller and Amal Rassam, "The View from the Court: Moroccan Reactions to European Penetration during the Late Nineteenth Century," International Journal of African Historical Studies 16, no. 1 (1983): 25-38; Leland Bowie, "An Aspect of Muslim-Jewish Relations in Late Nineteenth-Century Morocco: A European Diplomatic View," International Journal of Middle East Studies 7, no. 1 (1976): 3-19; Mohammed Kenbib, Les protégés: Contribution à l'histoire du Maroc, preface by Daniel Rivet (Rabat, 1996).

${ }^{7}$ This shift was epitomized by the consuls' cessation of the practice of kissing the bey's hand (L. Carl Brown, The Tunisia of Ahmad Bey, 1837-1855 [Princeton, NJ, 1974], 9, 232; on this tradition as practiced earlier, see Windler, Diplomatie, 432-38). On the relationship between the beys and European powers more generally, see Windler, Diplomatie, passim and esp. 224-30, 266-77; Asma Moalla, The Regency of Tunis and the Ottoman Porte, 1777-1814: Army and Government of a North-African Ottoman Eyâlet at the End of the Eighteenth Century (London, 2004). For a variety of reasons, including the revocation of the Edict of Nantes, French subjects taking up residence in Tunisia had not always wished to fall under consular authority. Beginning in the nineteenth century, however, consuls demanded that the bey cease according protection to Christians trying to escape consular authority. A treaty from 1824 
in Tunisia, Cambon realized that he could ill afford similar strikes at his legitimacy. In order to establish civilian-and not just military-authority over Tunisia, Cambon resolved to end the claims to extraterritorial sovereignty maintained there by France's imperial rivals. Otherwise, French leaders would find themselves as cornered as the Ottoman Porte, which had struggled to end the abuses of the capitulatory regime since at least the $1850 \mathrm{~s}^{8}{ }^{8}$

Cambon eventually got his way, as deals were negotiated with Great Britain, Italy, and other European states operating consular courts in Tunisia to cede their extraterritorial rights to France. In exchange, French jurisdiction would extend to all "Europeans." The arrangement rested on a simplistic

subjected "all French indiscriminately" to consular jurisdiction. A similar treaty had been concluded between Great Britain and the bey in 1812 (Windler, Diplomatie, 271-77). See also Mongi Smida, Consuls et consulats de Tunisie au XIXe siècle (Tunis, 1991); and Brown, Tunisia of Ahmad Bey, 241-44. Brown notes (238-40) that new challenges to beylical autonomy also came from a newly assertive Ottoman Empire, which reestablished direct control over Tripolitania (in modern Libya) in the wake of France's conquest of Algeria.

${ }^{8}$ The Capitulations were partially to blame for the Crimean War, as Russia exploited the concept to claim the right to protect all Orthodox Christians in the Ottoman Empire. Tunisia's obligation, as an Ottoman province, to raise armies in the Ottoman defense led indirectly to the establishment of the French protectorate, inasmuch as the vast debt Tunisia thereby incurred contributed to its placement in international financial receivership from 1869. France agreed to assume responsibility for Tunisia's debt and abolished the International Financial Commission after establishing the protectorate.

${ }^{9}$ Cambon was well aware that this was not the only way of reorganizing Tunisia's justice system. In Egypt, for instance, a system of "mixed tribunals" adjudicating civil and commercial disputes between claimants and defendants of different nationalities was established by fourteen European powers in 1876. The French initially had been wary of the mixed tribunals, though they managed to force a Napoleonic legal system upon the courts. Britain, for its part, had an interest in courting the French to maintain Anglo-French control of Egyptian finances (Roger Owen, Lord Cromer: Victorian Imperialist, Edwardian Proconsul [Oxford, 2004], chap. 8). By the time the courts came up for renewal after a five-year trial period, however, Great Britain stood poised to edge out French influence in Egypt. From this point forward, the French came to see the mixed courts as a way of checking Britain's ability to extend its influence in Egypt. The mixed courts did not do away with the Capitulations, and, as French authorities knew well from their experience in Egypt, "consenting to restrictions on capitulatory privileges would only strengthen the British position" (Nathan J. Brown, "The Precarious Life and Slow Death of the Mixed Courts of Egypt," International Journal of Middle East Studies 25, no. 1 [February 1993]: 37, 33-52). Cambon surely feared that Britain and other powers could endeavor to do in Tunisia what France had done in Egypt if the Capitulations were maintained or if a system of mixed courts were established. Cambon's detractors - both those in favor of abandoning the protectorate and those advocating its direct annexation-also saw the Capitulations, and the Bardo Treaty's recognition of them, as an obstruction to French influence (Ali Mahjoubi, 
understanding of "European" and "local" as clearly bounded identities: France would "protect" local sovereignty and the judicial practices associated with it for "natives," while "Europeans"- as "foreigners"- would fall under French authority. Yet this conception of "local" and "European" failed to account for the fluidity of social life in Tunisia - a veritable crossroads of the Mediterranean where Muslims, Jews, and (thanks to recent migration) Christians of diverse regional origins had become accustomed to maneuvering within systems of legal pluralism to take advantage of whichever laws best furthered their social goals in a given instance. ${ }^{10}$ The advent of the protectorate did not entirely curtail this flexibility. One thing that did change, however, was the manner in which such shifting allegiances engaged the international system, itself increasingly organized around distinct national states whose claims for legitimacy often rested on the notion of comprehensive and exclusive territorial sovereignty. ${ }^{11}$ Underlying the French legal system in Tunisia was an assumption that all Europeans shared interests at the very moment that their states sparred with each other throughout Africa for influence. In fact, however, the coincidence of renewed imperial rivalry and a burgeoning international state system helped encourage local-level scrambles for influence between European states while at the same time giving new meaning to Maghribians' legal strategies. ${ }^{12}$ Although the social motivations for such legal maneuverings remained similar to those of the precolonial period, the conse-

L'établissement du protectorat français en Tunisie [Tunis, 1977], 59ff). Thanks to Roger Owen for sharing thoughts with me on Anglo-French relations in regard to Egypt's legal system.

${ }_{10}$ The legal pluralism of the preprotectorate era laid the groundwork for the social uses of the law that persisted under protectorate rule and that are the subject of this article. For more on such practices in the precolonial era, see Clancy-Smith, "Marginality and Migration," and "Women, Gender, and Migration."

${ }^{11}$ Though this process took centuries, scholars generally agree that the European territorial state was "consolidated" by the end of the nineteenth century. See, e.g., Charles Tilly, "Reflections on the History of European State-Making," in The Formation of National States in Western Europe, ed. Charles Tilly (Princeton, NJ, 1975), and "States and Their Citizens," in Coercion, Capital, and European States, AD 990-1992 (Malden, MA, 1992); James Sheehan, "The Problem of Sovereignty in European History," American Historical Review 111, no. 1 (February 2006): 1-15. For an exploration of the related concept of "territoriality" and its rise in the same era, see Charles S. Maier, "Consigning the Twentieth Century to History: Alternative Narratives for the Modern Era," American Historical Review 105, no. 3 (June 2000): 807-31. On the uneven diffusion of the centralized state model, see C. A. Bayly, "Myths and Technologies of the Modern State," in The Birth of the Modern World, 1780-1914 (Malden, MA, 2004). For a critique of the exclusivity thesis, see Stephen D. Krasner, Sovereignty: Organized Hypocrisy (Princeton, NJ, 1999).

${ }^{12}$ The term "Maghribians" refers to the people of the Maghrib (Arab lands of the "West"-in common usage, the western portion of North Africa, including Morocco, 
quences of such practices changed as a newly competitive state system emerged.

Thus, while Cambon's reforms succeeded in closing the consular courts, France nonetheless remained constrained throughout the tenure of its protectorate by the interpenetration of international interests and domestic civic life in Tunisia. Efforts to control these dynamics eventually brought France to reverse course with respect to Tunisia in the 1920s, by which time it claimed no longer merely to protect but also to share in the Tunisian bey's sovereignty.

Two junctures in jurisdictional politics illumine the nature of France's changing relationship with its imperial rivals and Tunisia's diverse populations. Defined by Lauren Benton as "conflicts over the preservation, creation, nature and extent of different legal forums and authorities," jurisdictional politics were what Cambon thought he had done away with when he closed the consular courts. ${ }^{13}$ Instead, they persisted in another form. First, the suppression of European consular courts in the 1880s engendered novel legal maneuvers by individuals living in Tunisia that had the effect, if not always the intent, of exposing the limits of French authority in the protectorate. Second, Tunisian "natives" adopted jurisdictional strategies in the 1910s that built on-and sometimes intensified — new tensions in Mediterranean politics that followed Italy's invasion of Libya and France's establishment of a protectorate over Morocco. Both of these moments show the French administration struggling to strike a balance between demonstrating its power and accommodating conflicting interests. On the one hand, French authorities used what John Comaroff has described as "lawfare" to consolidate their position in the protectorate. ${ }^{14}$ On the other hand, the protectorate, as a "wonderfully flexible legal instrument," 15 proved sometimes too flexible for French liking because it created the conditions for instrumentalizing allegiance, opening up spaces for foreign nationals and native subjects to exploit the limitations of French power. ${ }^{16}$ Over time, the confrontations and negotiations engendered by

Algeria, and Tunisia). It is used in contrast to "Mashriq," which refers to the Arab lands of the "East."

${ }^{13}$ Lauren Benton, Law and Colonial Cultures: Legal Regimes in World History, 1400-1900 (Cambridge, 2002), 10.

${ }^{14}$ John L. Comaroff's characterization of the "effort to conquer and control indigenous peoples by the coercive use of legal means," in Comaroff, "Colonialism, Culture, and the Law: A Foreword," Law and Social Inquiry, 2001, 306.

${ }^{15}$ Antony Anghie's characterization of the protectorate form of rule in Anghie, "Finding the Peripheries: Sovereignty and Colonialism in Nineteenth-Century International Law," Harvard International Law Journal 40 (Winter 1999): 57.

${ }^{16}$ This was not only true of Tunisia. As Sara Berry has shown in her work on sub-Saharan Africa, indirect rule- however flexible in theory-institutionalized struggle in practice. See Berry, "Hegemony on a Shoestring: Indirect Rule and Access to 
this disjuncture between lawfare and the social uses of the law brought French authorities to intervene more directly in Tunisian life.

From the 1880 s, the desire to prove themselves masters not only to the bey's subjects but also to European rivals led French authorities to subject Europeans living in the protectorate to a common rule of French law. They aimed to do this by substituting French courts for the various consular courts which had operated under the Capitulations. In order to secure this reform, however, France had to grant concessions to the same foreign governments whose influence it sought to diminish. French courts thus found themselves enforcing European laws that conflicted with French civil and penal codes. Particularly exasperating to French authorities was the fact that their own courts applied various European laws not only to individuals whom they agreed were European but also to persons whom they regarded as Tunisian subjects. At the turn of the twentieth century, the tendency of native Muslims and Jews to try to escape beylical jurisdiction led French authorities, in concert with the bey, to discontinue the system whereby foreign countries could offer "patents of protection" to the bey's subjects. By the 1910s, however, native subjects found new ways to play jurisdictional politics: claiming to possess the "nationality" of one or another European power by virtue of birth in a territory (Libya, Algeria, Malta, etc.) controlled by Europeans. As such legal maneuvers in Tunisia aggravated conflicts between France and other European states, French officials tried to regain control by, first, endeavoring to ascribe French nationality to all "Europeans" and, second, imposing a single "Tunisian nationality" on all Muslims and Jews, hitherto mere "subjects" of the bey. So recast, the Franco-Tunisian relationship presented new challenges to French rule in the protectorate and at the same time altered the geography of power throughout North Africa. ${ }^{17}$

Agricultural Land," Africa: Journal of the International African Institute 62, no. 3 (1992): 327-55.

${ }^{17}$ This process resembles the tendency of colonial states to be "drawn in" as arbiters of legal pluralism, as described by Benton, Law and Colonial Cultures, 29, with an important exception: while Benton describes European colonial states that, frustrated by the indeterminacy of "truly plural legal orders" (28), increasingly tried to impose order by extending a single jurisdiction to all persons living in a particular territory, France never purported to treat Tunisia as a single jurisdiction. Instead, French authorities intervened increasingly in an effort first to impose a single (French) jurisdiction on all "Europeans" and then to impose a single nationality (Tunisian) on all Muslims and Jews, without ever claiming to include "Tunisians" within the French jurisdiction. This particular brand of creating "order out of trouble," as Benton calls it (chap. 3), contributed to the growth of Tunisian nationalism by helping to establish the legal category "Tunisian nationals"-where once there had been subjects of the bey. 


\section{REMAPPING the History OF EMPIRE}

In suggesting that the international order in the Mediterranean basin and the Tunisian civic order mutually constituted one another, I am calling for a new way of thinking about what Frederick Cooper and Ann Stoler have termed the "tensions of empire." Cooper and Stoler, along with other "new imperial historians," fruitfully pushed past the nationalist paradigms that had dominated histories of empire and suggested instead that scholars place metropole and colony in a single analytic field. ${ }^{18}$ Very few scholars, however, have broadened this scope of inquiry beyond the presumed closed circuit of metropole and colony. ${ }^{19}$ In connecting local social strategies to imperial rivalries, I integrate approaches to the history of empire that, because of their isolation from one another, have missed the specific ways in which imperial power has been exercised, contested, and transformed. Attention to such specificity has sometimes been lacking in the otherwise rich analyses of imperialism and colonialism that have proliferated over the past few decades. ${ }^{20}$ Much has been made, for instance, of the imperialists' need to erect and enforce boundaries, whether physical or ideological, sexual or affective. Such boundaries were crucial to producing colonial knowledge and claiming the "prestige" of a "civilizing" power. ${ }^{21}$ Although few analyses of imperialism would deny its

${ }^{18}$ Frederick Cooper and Ann Laura Stoler, "Between Metropole and Colony: Rethinking a Research Agenda," in Tensions of Empire: Colonial Cultures in a Bourgeois World, eds. Cooper and Stoler (Berkeley, 1997), based on a special issue of American Ethnologist 16, no. 4 (1989). See also A New Imperial History: Culture, Identity and Modernity in Britain and the Empire, 1660-1840, ed. Kathleen Wilson (Cambridge, 2004).

${ }^{19}$ Among the pioneers are Julia A. Clancy-Smith, Rebel and Saint: Muslim Notables, Populist Protest, Colonial Encounters (Algeria and Tunisia, 1800-1904) (Berkeley, 1994); Matthew Connelly, A Diplomatic Revolution: Algeria's Fight for Independence and the Origins of the Post-Cold War Era (Oxford, 2002); Thomas Metcalf, Imperial Connections: India in the Indian Ocean Arena, 1860-1920 (Berkeley, 2007). Others making similar suggestions include Durba Ghosh and Dane Kennedy, "Introduction," in Decentering Empire: Britain, India and the Transcolonial World, eds. Ghosh and Kennedy (Andhra Pradesh, 2006), 1-15. In particular, Clancy-Smith's pathbreaking Rebel and Saint integrated the study of Algeria and Tunisia, showing how the actions of ordinary people living in this transborder region helped shape the expansion of France's imperial holdings in North Africa.

${ }^{20}$ For an excellent summary, see Frederick Cooper, Colonialism in Question: Theory, Knowledge, History (Berkeley, 2005). Cooper finds fault with scholarship that implies an "essence of being colonized independent of what anybody did in a colony" (17).

${ }^{21}$ There is a vast literature on colonial boundary drawing in the second wave of European imperialism. For the French case, these include Ann Laura Stoler, Carnal Knowledge and Imperial Power: Race and the Intimate in Colonial Rule (Berkeley, 2002); David Prochaska, Making Algeria French: Colonialism in Bône, 1870-1920 (Cambridge, 1990); Gwendolyn Wright, The Politics of Design in French Colonial 
tangible effects on human societies, the emphasis has often been on the more intangible realm of "ideas." Edward Said, whose Orientalism helped spark the field of colonial and postcolonial studies, remained convinced, even in his later work, that the material aspects of imperialism had been overemphasized. "Territories are at stake, geography and power," he wrote in the introduction to Culture and Imperialism, but the contest over geography "is complex and interesting because it is not only about soldiers and cannons but also about ideas, about forms, about images and imaginings." ${ }^{22}$ To be sure, such images and imaginings may have betrayed an ambivalence that opened spaces for subversion, as Homi Bhabha suggests. ${ }^{23}$ Yet for all these cultural analyses tell us about the general dynamic of imperialism, we have often been left wanting when it comes to details. ${ }^{24}$ If imperialism was about form, how did change come about? If subversion was a constant feature of colonial societies, then how can we explain the long persistence of imperial power?

Surely there is no universal answer to these questions. We need a methodological framework that transcends neat oppositions between colonizer and colonized without denying uneven distributions in power. ${ }^{25}$ If relations between metropole and colony did not operate in a vacuum, then historians too must expand their vision to include neighboring colonial territories, the range of imperial powers active in the area, and individuals who traversed these boundaries themselves or called them into question through their behavior. Colonial boundaries, however ideational, depended on and contributed to geopolitics. By this I do not mean simply the defense of borders-by soldiers or cannons - but rather the many other ways in which defending interests and exercising influence in the context of imperial rivalry affected what one might call, following Elizabeth Thompson, the "colonial civic order." Drawing on

Urbanism (Chicago, 1991); Alice Bullard, Exile to Paradise: Savagery and Civilization in Paris and the South Pacific, 1790-1900 (Stanford, CA, 2000). Patricia Lorcin's work shows how colonial power was buttressed by boundary drawing between sectors of the colonized population, in this case by playing up differences between "Berbers" and "Arabs." See Lorcin, Imperial Identities: Stereotyping, Prejudice and Race in Colonial Algeria (London, 1995).

${ }^{22}$ Edward Said, Culture and Imperialism (1993; repr., New York, 1994), 7.

${ }^{23}$ Homi Bhabha, "Of Mimicry and Man: The Ambivalence of Colonial Discourse," in Cooper and Stoler, Tensions of Empire, 152-60.

${ }^{24}$ An important exception is Clancy-Smith's Rebel and Saint, which connects cultural, economic, and political behavior (see n. 19).

${ }^{25}$ On this point, see, in addition to n. 19, Frederick Cooper, "Conflict and Connection: Rethinking Colonial African History," American Historical Review 99, no. 5 (December 1994): 1516-45 and esp. 1531-34; and Pier M. Larson, " "Capacities and Modes of Thinking': Intellectual Engagements and Subaltern Hegemony in the Early History of Malagasy Christianity," American Historical Review 102, no. 4 (October 1997): 969-1002 and esp. 970, 978. 
Isser Woloch's definition of civic order, Thompson has in mind the matrix of institutions, expectations, and practices that governed collective life-that managed relations among individuals or groups, as well as between them and the colonial state. ${ }^{26}$

No colonial civic order can or should be divorced from the international order, but the connection between the two was felt particularly strongly in Tunisia for two reasons. First, European powers-especially Italy and Great Britain-retained an interest in the territory after France assumed protector status, principally because their nationals outnumbered the French in the settler population. In the domain of law, this engendered divisions not only between colonizer and colonized but also within the settler population. Second was Tunisia's location, which gave it strategic importance far beyond its size. Encompassing approximately 162,000 square kilometers wedged between Libya (more than 1.7 million square kilometers) and Algeria (almost 2.4 million square kilometers), less than 350 kilometers from the British crown colony of Malta and a mere 150 kilometers from Sicily, Tunisia was also uniquely situated in relation to its colonial neighbors. The border it shared with Algeria was, in a sense, also one with France, since the northern third of Algeria had been annexed as three departments in 1848 and was considered an integral part of French territory. After Italy annexed Tripolitania and Cyrenaica in 1912, Tunisia also could be said to share a border with Italy. Whatever advantages French authorities, like so many other imperialists in this era, saw in ruling Tunisia indirectly, ${ }^{27}$ they could not administer much of

${ }^{26}$ Elizabeth Thompson, Colonial Citizens: Republican Rights, Paternal Privilege and Gender in French Syria and Lebanon (New York, 2000), esp. 1-3; Isser Woloch, The New Regime: Transformations of the French Civic Order, 1789-1820s (New York, 1994), esp. 14-15. In borrowing this term, I am by no means suggesting that Tunisia's civic order resembled that of Syria, Lebanon, or France. Rather, I find the term analytically useful in a more general sense.

${ }^{27}$ The turn to "indirect rule" is a late nineteenth-century development common to all major imperial powers. It can be linked to the expansion of democratic politics in metropolitan centers, whose constituencies - while happy to benefit from empire-did not want to pay for it, literally or figuratively. A related argument for indirect rule claimed that, by maintaining a territory's "natural" rulers, the metropole would encounter fewer security problems. This "respect" for native custom was, in turn, surely related to the concomitant rise of the study of human difference, which, at its most extreme, took the form of so-called scientific racism. Finally, there was also the pragmatic consideration of the "flexibility" offered by the very ambiguity of the protectorate form. See Anghie, "Finding the Peripheries"; Peter Burroughs, "Imperial Institutions and the Government of Empire," in The Oxford History of the British Empire, vol. 3, The Nineteenth Century, ed. Andrew Porter (Oxford, 1999), chap. 9; Martti Koskenniemi, The Gentle Civilizer of Nations: The Rise and Fall of International Law, 1870-1960 (Cambridge, 2001), esp. chap. 2. Within the realm of symbolic politics, moreover, terms like "protectorates" and "leases" sounded less "imperial" in the age of mass democracy. This is what made the latter particularly attractive to what 
anything in the protectorate without reference to the very different regime of their colony in neighboring Algeria or those of their imperial rivals in the region. Recognizing the significance — not to mention permeability — of borders does not entail reviving the narrowly defined political histories to which Said rightfully objected. Instead, I offer a new approach to imperial and colonial history by placing social life-or culture, in the anthropological sense- and diplomacy within a single analytic frame. ${ }^{28}$ Integrating the political, social, and cultural histories of empire in this way offers a fuller understanding of colonial power as well as its limits. ${ }^{29}$

That said, broadening the scope of analysis does not explain how all colonial systems operated at all times. This is not a quest for a universal explanation of colonial power. Rather, I propose a method that, while applicable to other colonized territories, is only useful inasmuch as it yields insight about the specific relationships set into play in particular places. In all colonial legal pluralisms, "native" law is distinguished from that of the colonizing power. ${ }^{30}$ What made the situation in Tunisia distinctive after 1881 was the way that its legal pluralism implicated foreign states, setting in motion conflicts at

we might call anti-imperialist imperial states, such as the United States. See Amy Kaplan, "Where Is Guantánamo?" American Quarterly 57, no. 3 (September 2005): 831-58. For Anthony Pagden, the turn away from direct rule carried the seeds of self-determination, even if these were not apparent at the time ("Fellow Citizens and Imperial Subjects: Conquest and Sovereignty in Europe's Overseas Empires," History and Theory 44 [December 2005]: 28-46).

${ }^{28}$ As Ghosh and Kennedy argue, histories of "imperialism" and "colonialism" can and should be bridged. Ghosh and Kennedy, "Introduction," 5.

${ }^{29}$ A number of publications point the way toward this kind of analysis, though only one concerns French North Africa. See esp. Clancy-Smith, Rebel and Saint; Frederick Cooper, Decolonization and African Society: The Labor Question in French and British Africa (Cambridge, 1996); Laurent Dubois, A Colony of Citizens: Revolution and Slave Emancipation in the French Caribbean, 1787-1804 (Chapel Hill, NC, 2004); Gregory Mann, Native Sons: West African Veterans and France in the Twentieth Century (Durham, NC, 2006); Richard Roberts, Litigants and Households: African Disputes and Colonial Courts in the French Soudan, 1895-1912 (Portsmouth, NH, 2005); Thompson, Colonial Citizens.

${ }^{30}$ The literature on legal pluralism in colonial contexts is too vast to cite in its entirety here; for an excellent overview through 1988, see Sally Engle Merry, "Legal Pluralism," Law and Society Review 22, no. 5 (1988): 869-96. Subsequent scholarship includes Law and Colonialism in Africa, ed. Kristin Mann and Richard Roberts (Portsmouth, NH, 1991); Roberts, Litigants; Benton, Law and Colonial Cultures; Emmanuella Saada, "Citoyens et sujets de l'empire français: Les usages du droit en situation coloniale," Genèses 53 (2003): 4-24. Because Tunisia had a long history of both beylical and Islamic justice, its legal traditions were not "invented" out of whole cloth by colonial administrators, as has sometimes been suggested with regard to other colonial contexts. 
once local and international that led, over time, to changes in protectorate governance. Imperial rivalry did not merely consist of intermittent crises resolved by gunboat politics; rather, it provided a constant undercurrent to life in the empire, intermingling with the logic of social and legal behavior across and within colonies. Moreover, as everyday behavior was affected by international relations, so too did it transform them. Together, international disputes and local-level conflicts challenged French authority in the protectorate and, in turn, reshaped the imperial game across the Mediterranean and North Africa.

\section{ENDING EXTRATERRITORIALITY?}

France launched its invasion of Tunisia on April 24, 1881, on the pretext that members of the Khmir tribe threatened France's colony in neighboring Algeria by pursuing their feuds across the border. In fact, however, plans for France to take Tunisia had been brewing for years. Tunisia's finances had been controlled since 1869 by an International Finance Commission made up of Great Britain, Italy, and France. Since that time, each of these three European governments had jockeyed for position as the "preponderant." At the Berlin Congress of 1878, convened to settle disputes arising from the Russo-Turkish war, exchanges between the French and British delegationsencouraged by the German Chancellor Otto von Bismarck-opened the way to France extending its influence in Tunisia. ${ }^{31}$ France had long been concerned to protect its position in Algeria, where a state of rebellion continued on and off for two decades following the 1830 invasion. At midcentury, the increasing reliance of Algerian rebels on Tunisian support had brought the French to intervene more directly on the Tunisian-Algerian border. Indeed, according to Julia Clancy-Smith, “Tunisia's open-door policy toward Algerian émigrés was one element, among several, that eventually brought its forced incorporation into France's expanding empire." Thus, defending Algeria became an impetus for French imperial expansion throughout North Africa, and the process that set this in motion considerably predated the $1880 \mathrm{~s}^{32}$ Even after the Berlin Congress, however, wariness of upsetting Italy stalled the project of taking all Tunisia. In the three years between the Congress and the French

${ }^{31}$ Political historians generally agree that discussions occurred at the congress that helped pave the way to France claiming Tunisia, though they disagree on the extent to which Britain overtly endorsed the idea. For an account downplaying Britain's endorsement, see the argumentatively imbalanced but well-researched Arthur Marsden, British Diplomacy and Tunis, 1875-1902: A Case Study in Mediterranean Policy (New York, 1971); for an equally well-researched account that is imbalanced toward the French, see Jean Ganiage, Les origines du protectorat français en Tunisie (18611881), 2nd ed. (Tunis, 1968).

${ }^{32}$ Clancy-Smith, Rebel and Saint, 8, 258; see also chap. 6. 
invasion, France and Italy competed for influence in the Regency, mostly by sparring over banking, railroad, port, and other monopolies. What the French government viewed as Italian "provocations" in these domains led to its quest for a casus belli. To maintain European comity, better to blame the Tunisians themselves.

The French forces arrived at Ksar Said, the beylical palace at Bardo, on May 12, 1881, and gave Muhammed al-Sadiq Bey three hours to respond to an ultimatum. The resulting treaty was formally an agreement between France and the bey. But it really engaged many other interests, for France had to ensure the approbation of its foreign rivals. This was one reason the French did not seek to annex Tunisia outright. Another was that annexation had proved costly - in both real and moral terms - in Tunisia's neighbor Algeria. Moreover, a France still smarting from Germany's annexation of Alsace and Lorraine following France's 1871 defeat in the Franco-Prussian War could hardly condone occupation as a strategy of rule. Jules Ferry, the president of the Council of Ministers, who faced extraordinary opposition in parliament regarding the invasion in part for this reason, ultimately resigned under pressure.$^{33}$ Tunisia, his opponents contended, was a distraction from France's true interests - and one aided and abetted by Bismarck, to boot. The fact that France would alone become the guarantor of Tunisia's debt also infuriated members of parliament. ${ }^{34}$ For all these reasons, the protectorate was a carefully crafted compromise. Not only did France pledge to protect the bey's dynasty, it also promised to guarantee all preexisting international agreements between the bey's government and other states. In this way, the Bardo Treaty recognized, tacitly, both the bey's sovereignty and the interests of other powers in Tunisia-most notably but not exclusively those of Italy and Britain. $^{35}$

Two years later, the June 8, 1883, Convention of La Marsa provided the outlines for French intervention in Tunisia's domestic affairs without abandoning the basic precept of nominally recognizing the bey's sovereignty. What constrained France more than the domestic sovereignty retained by the bey, however, were his treaty agreements with other European powers. These treaties granted commercial privileges, diplomatic immunities, and, most crucially, capitulatory rights. The maintenance of the Capitulations meant that each consular court of every European power exercised a form of sovereignty in the protectorate. Moreover, because this sovereignty was jurisdictional

${ }^{33}$ Ferry became premier again in 1883 , until another colonial adventure, this time in Indochina, ended his second government.

${ }^{34}$ Debate in the Chamber of Deputies, December 1, 1881, Annales de la Chambre des Députés (1881), 313-32; Debate in the Chamber of Deputies, July 17-18, 1882, Annales de la Chambre des Députés (1882), 917-73.

${ }^{35}$ Treaty between France and Tunis, May 12, 1881. See n. 3. 
(applying to persons) rather than territorial (applying to places), its effects were diffuse. ${ }^{36}$ At the time the protectorate was established, its residents included approximately 11,200 Italians and 7,000 British subjects (mostly Maltese), as well as a smattering of Greeks, Dutch, and other foreign nationals. The size of France's settlement, at a mere 700, paled in comparison. Equally concerning were the protégés-native Jews and Muslims who had secured the legal protection of one or another European government. In short, if the extraterritorial sovereignty of other European states, especially Britain and Italy, were allowed to persist, these states-more so than France-would effectively be responsible for the rule of law in Tunisia. That is what Cambon meant when he said France would be cornered if the Capitulations were not suppressed.

To address this problem, French authorities first needed to establish a new justice system. They accomplished this by passing a law in parliament on March 27, 1883, made applicable in Tunisia through a beylical decree of April 18. A few weeks later, another beylical decree extended the jurisdiction of French courts to the nationals of foreign countries having renounced their capitulatory rights. Thus, a system of dual jurisprudence was established. For all civil matters and everything but felonious crimes against European persons or property, ${ }^{37}$ Tunisian subjects would continue to fall under the jurisdiction of native courts, which consisted of secular administrative courts as well as sharia and rabbinical courts. ${ }^{38}$ In practice, the native justice system relied on qaids (Muslim local officials) to render justice swiftly; cases were to be referred to the court system only if they "exceed[ed]" the qaid's "expertise."39 Europeans, once the consular courts were closed, would fall under the juris-

${ }^{36}$ On the distinction between jurisdictional and territorial sovereignty, see esp. Peter Sahlins, Boundaries: The Making of France and Spain in the Pyrenees (Berkeley, 1989).

${ }^{37}$ French law distinguishes crimes (roughly comparable to felonies) from délits (roughly comparable to misdemeanors). Tunisians accused of committing a crimesuch as murder-were tried by French courts when the victim was European. Lesser délits initially were judged by the local justice system. European defendants always retained the right to be tried in European courts, regardless of the identity of the victim.

${ }^{38}$ A dual system of law was also established in neighboring Algeria. However, unlike in Tunisia, where native courts remained under the nominal jurisdiction of the bey, in Algeria the Roman law tradition was grafted onto Islamic legal practices, transforming what had been a flexible legal system into a highly bureaucratized one. The most comprehensive account of this transformation is Allan Christelow, Muslim Law Courts and the French Colonial State in Algeria (Princeton, NJ, 1985). As Christelow points out, by institutionalizing Muslim law in this way, France reinforced an Algerian Islamic identity and impeded change in interpretation of Islamic law.

${ }^{39}$ Circular to Qaids, April 10, 1886, cited in Mohamed Dabbab and Tahar Abid, La justice en Tunisie: Histoire de l'organisation judiciaire (essai): De 1856 à l'Indépendance (Tunis, 1998), 124. 
diction of French courts. Reforms later made Tunisians subject to French jurisdiction in cases where they were accused of committing misdemeanors against the person or property of a European. And once land law reforms were instituted in 1885 , disputes relating to "registered" property also would be settled by the French court. ${ }^{40}$

With the framework for French legal institutions in place, the Ministry of Foreign Affairs set about convincing European governments to close their consular courts. The process took over a year. Many governments wanted their nationals indemnified for damages to their property occurring during the French invasion and subsequent resistance movement before they would close their courts ${ }^{41}$ Although almost no government went quietly, Italy's protests were the loudest. Writing to the Italian ambassador in Paris, the Italian Minister of Foreign Affairs Pasquale Mancini stressed that France had not yet "adequately taken into account the political and parliamentary constraints" that his government was under. ${ }^{42}$ As Mancini explained, "It isn't ... that I wish to evade my commitments [to France], as is believed in Paris and as perhaps the French ambassador himself believes.... But the government of the Republic must understand that in order to pass these agreements, I have to be fully armed, to be in a position to respond to every objection that is

40 The 1885 property law was designed to circumvent the fact that property previously fell entirely under the jurisdiction of Islamic courts. By creating the possibility of property "registration" (immatriculation), the 1885 law gave a legal "personality" to registered property. The law was based primarily on the French Civil Code but apparently drew inspiration from Australian land law as well. Newly established "mixed" Franco-Tunisian courts would be responsible for registering property; once property was registered, it would be adjudicated by French courts. For the development of French justice in Tunisia, see Dabbab and Abid, La justice en Tunisie; Ali Noureddine, La justice pénal française sous le protectorat: L'exemple du Tribunal de première instance de Sousse (1888-1939) (Tunis, 2001); Mahjoubi, L'établissement du protectorat, esp. chap. 5; Kenneth J. Perkins, A History of Modern Tunisia (Cambridge, 2004), chap. 2. On the property law in particular, see Béchir Yazidi, $L a$ politique coloniale et le domaine de l'état en Tunisie, de 1881 jusqu'à la crise des années trente (Tunis, 2005), 44-53; P. Piollet, Du régime de la propriété foncière en Tunisie (Paris, 1897); Georges Soulmagnon, La loi tunisienne du ler juillet 1885 sur la propriété immobilière et le régime des livres fonciers (Paris, 1933).

${ }^{41}$ A. Rayaudi-Massiglia, Consolato generale in Tunisi al Ministro degli affari esteri, September 25, 1883, and November 27, 1883, in Documenti Diplomatici relativi alla sospensione della giuridizione consolare italiana in Tunisia (1882-84), presentati dal Ministro degli Affari Esteri Mancini nella tornata delli 28 febbraio 1884 (Rome, 1884), 100-101, 126-29. See also Archives du Ministère des Affaires Étrangères Nantes, Tunisie, protectorat, 1er versement (hereafter AMAE/Nantes/Tun.-1er v.), 1219.

42 Il Ministro degli affari esteri al R. Ambasciatore in Parigi, November 29, 1883, Documenti Diplomatici, 120, 119-25. 
presented to me, to reply to all questions that I am asked." 43 The French had reason to be wary-Mancini had been instrumental in concluding the Triple Alliance, which had come to public attention earlier that year and by which Germany and Austria-Hungary promised to assist Italy if it were attacked by France. With the state of European affairs as such, France's hands were tied. France had won Tunisia, but this had not given it free rein.

Italy demanded first that its 1868 treaty with Tunisia remain in effect, guaranteeing certain commercial privileges and the principle of Capitulations-Italy would suspend indefinitely, rather than permanently discontinue, the operation of its consular courts. In addition, it placed conditions on recognizing French jurisdiction: half of any jury in a trial concerning an Italian defendant should be composed of Italian nationals; Italian nationals should be admitted to the French bar, magistracy, and court employment; Italian law should be applied to Italian nationals in matters pertaining to personal status; Italian protégés should be treated as Italian nationals; and, finally, Italians found guilty of capital crimes should be spared the death penalty.

Among the Italian demands, the ones regarding jurors, lawyers, and the death penalty posed the greatest problems for the French government. France did not want to grant Italy concessions that were different from those enjoyed by other states, considering itself "obliged to uphold a common standard which offers the same guarantees to all foreigners." 44 Only Italy, and perhaps the British crown colony of Malta, could claim to have enough nationals in Tunisia to make the insistence on jury representation realistic. In the end, France gave Italians and British subjects the opportunity to request a jury pool half composed of fellow nationals. With respect to attorneys and magistrates, France initially maintained that Italians wishing access to the magistracy would have to be trained in French courts. But when Italy refused this condition, the French conceded that those currently employed as defense attorneys or magistrates at the Italian consular court would be allowed to continue in the French courts, while future magistrates could complete their training under an Italian prosecutor. The death penalty stipulations were the most contentious. France claimed that its courts in Tunisia ruled in the name of the French state according to French law; it was therefore inadmissible to modify procedure for Italians with respect to presidential pardons in capital cases, for the French parliament no doubt "would refuse to sanction such an attack on the principle of national sovereignty." ${ }^{5}$ Here too, France secretly surrendered: "The French Government consents to this engagement, but it

${ }^{43}$ AMAE/Nantes/Tun.-1er v., 1219: Mancini is quoted in Ambassador Decrais to Jules Ferry, Rome, December 6, 1883.

${ }^{44}$ AMAE/Nantes/Tun.-1er v., 1219: Réponse à l'aide memoire remis par le gouvernement italien le 18 juillet 1883.

${ }^{45}$ AMAE/Nantes/Tun.-1er v., 1219: Marquis de Reverseaux, French chargé 
cannot do so in a public document without prejudicing the exercise of penal law with regard to Italian defendants." ${ }^{46}$ In January 1884, France and Italy signed a protocol suspending the Capitulations; its secret clauses caused a public scandal a decade later when three members of the Sicilian mafia committed a brutal double murder in Bir-Loubit, only to be spared execution by the French president-forced to honor his country's promises to the Italian government. ${ }^{47}$

While the impact of international relations on criminal law in Tunisia was important, its effect on civil law was even more pervasive. Because the diplomatic compromise affected marriage, divorce, inheritance, taxation, property rights, and other important domains of civil law, it greatly influenced the way people understood and experienced French power and, in so doing, shaped the Tunisian civic order. Residents of Tunisia exploited the ambiguity of the settlement, invoking whatever jurisdiction served their immediate interests. Thus, even after the French successfully negotiated the suppression of the Capitulations in treaties with European states, bringing all "Europeans" under the umbrella of the French courts did not necessarily bring them to identify with French legal norms, nor did it create a community of interest within the so-called European population.

Case law from the late nineteenth century demonstrates how the jurisdic-

d'affaires before the Italian government, to Minister of Foreign Affairs Paul-Armand Challemel-Lacour, Rome, October 18, 1883.

${ }^{46}$ AMAE/Nantes/Tun.-1er v., 1219: French response to communication of Italian Foreign Minister to Italian Ambassador in Paris dated Rome, November 29, 1883.

47 AMAE/Nantes/Tun.-1er v., 1219: Ministre des Affaires Étrangères, Direction des Affaires politiques, service des protectorats, à M. Millet, Résident Général de la République Française à Tunis, no. 341, May 25, 1895; République Française, Tribunal de Tunis, Cabinet du Président, Direction des Affaires Criminelles, A. Fabry to M. le Garde des Sceaux, March 5, 1895; Ambassadeur de la République Française à Rome au Ministére des Affaires Étrangères, February 23, 1895, and February 28, 1895; Note sous bordereau dated March 11, 1895 (Tribunal de Tunis au Résident Général); Résident Général M. Millet à M. le Ministre des Affaires Étrangères, no. 17, March 15, 1895, marked "confidentielle." France's commitment to Italy was particularly inopportune in this case, since two Tunisians were condemned to death the same day by the same court for crimes considered lesser by the court's president, leading him to wonder if there might not be some way around honoring the secret protocols. Within two years, however, he no longer objected to Italian immunities, concluding in a similar case that excessive concern for fairness toward Tunisian subjects in capital cases could appear indulgent, which in turn might undermine respect for the French rule of law if Muslims believed that they could attack a European with impunity. AMAE/Nantes/Tun.-1er v., 1219: A. Fabry to M. le Garde des Sceaux, March 6, 1895; Archives Nationales de Tunisie (hereafter ANT) E 147 dr. (dossier) 1: République Française, Tribunal de Tunis, Cabinet du Président, Direction des Affaires Criminelles, 1er bureau, February 27, 1897, signed A. Fabry. 
tional complexity of the Tunisian civic order penetrated family relationships. The treaties suspending the consular jurisdictions stipulated that in civil law matters-such as marriage, divorce, and inheritance-the personal, rather than residential, status of the individuals involved should determine which country's laws would be applied. Seemingly clear-cut, these provisions did not prevent individuals from trying to manipulate the new juridical situation to their personal advantage..$^{48}$ In 1896 , for instance, the surviving parents of a Maltese man tried to use the closure of the British consular court as an excuse to place the inheritance outside the boundaries of law, thereby honoring the wishes of the deceased, Francesco Nappa, who had written a will disinheriting his wife in favor of his parents. But Widow Nappa turned their jurisdictional game against them by suing her in-laws in French court. By virtue of the cession of Britain's capitulatory rights, the French court claimed jurisdiction over the case. Enlisting the advice of a Maltese lawyer, the court then applied the Maltese Code of Rohan, granting the widow one-quarter of her husband's estate, as was allowed for estates where there were no descendants, provided the surviving spouse had not disgraced the family and had no personal fortune of her own. ${ }^{49}$

The Nappas were hardly alone in attempting to use jurisdictional politics to settle intimate family disputes. In 1893, for instance, a man named André tried to claim that his wife had no right to divorce him because she was Italian and Italian law did not allow for divorce. The court found this argument moot because Antonia, although originally Italian, had automatically become French upon marrying André, and French law did allow for divorce. Moreover, her grounds for divorce were justified, as André maintained a concubine in the conjugal home and had fathered a child by his mistress. ${ }^{50}$ Other chastised husbands found French courts equally unaccommodating. Monsieur Calleja, a Maltese man, went so far as to appeal a legal separation judgment rendered in his wife's favor by the Tunis civil court, contending that it had no jurisdiction over British subjects. The Algiers appeals court found against him, ruling that, by virtue of the suspension of Great Britain's consular courts, both the Tunis court and Madame Calleja had been within their rights. ${ }^{51}$

${ }^{48}$ Thus, despite the new colonial legal regime, individuals maintained long-standing practices of working between conflicting jurisdictions. On these, see Clancy-Smith, "Women, Gender, and Migration," and "Marginality and Migration."

${ }^{49}$ Veuve Nappa c. Consorts Nappa, Tribunal de Tunis (1ère ch.), June 29, 1896, Jugement, in Revue Algérienne, tunisienne et marocaine de législation et de jurisprudence (hereafter RAT) (1897), pt. 2, 29-32.

${ }^{50}$ Indeed, the court found that André had been listed as French on his son's birth certificate. R....c. Dame R. ..., Tribunal de Tunis (1ère ch.), June 12, 1893, Jugement, in Journal des tribunaux français en Tunisie (hereafter JTT) (1894) 300302.

${ }^{51}$ Calleja c. Calleja, Cour d'Appel d'Alger (1ère ch.), November 10, 1890, 
Although these particular disgruntled husbands failed to evade or manipulate the law to their advantage, their effort to do so reflected a common strategy among men to maintain patriarchal power in the family - or perhaps a common reliance of women on courts to escape that patriarchy. Both tactics placed French judges in the position of adjudicating disputes between husbands and wives, as well as applying laws not of France's own making.

Consequently, instead of overseeing the application of a uniform rule of law to all Europeans, French judges in Tunisia found themselves adjudicating conflicts between diverse European civil and penal codes. France allowed for divorce; Italy did not. Spain recognized religious marriage; France recognized only civil marriage. Inheritance laws differed across European states and thus among European nationals in the protectorate. Faced with this legal pluralism, French courts applied foreign civil codes-first cautiously, by drawing on foreign legal advisors, then increasingly confidently, drawing on their own expertise.

\section{The Politics of Protection}

It was difficult enough to confront conflicts in international private law regarding individuals claiming European origins, but the legal conundra caused by persons whose status straddled the rigid division between "European" and "native" jurisdictions presented even more confounding problems. The beylical decree of May 5, 1883, had declared that "nationals of friendly states suppressing their consular courts will be subject to the jurisdiction of French courts in the same circumstances and conditions as the French themselves." 52 But the treaties and protocols that France subsequently signed in order to close the consular courts granted protégés these same rights. This state of affairs presented the protectorate administration with two problems. First, it allowed other European governments to maintain an influence by selling patents of protection. Second, and equally galling, it created circumstances in which foreign protégés obtained rights from which beylical subjects were excluded. Tunisians could reasonably wonder what benefit France's protection of the bey conferred when affiliation with another European state seemed sometimes to offer greater advantages. This was precisely the problem

Jugement, in JTT (1890), 306-7. A peculiarity of the Tunisian legal system was that, despite the protectorate having been fashioned as an alternative to the mode of rule adopted in Algeria, it shared the same appeals court until the 1940s.

${ }^{52}$ Décret du 27 Djoumadi-et-Tani 1300 (May 5, 1883), étendant aux étrangers la compétence des Tribunaux français, reprinted in Maurice Bompard, Législation de la Tunisie: Recueil des lois, décrets et règlements en vigueur dans la Régence de Tunis au ler janvier 1888 (Paris, 1888), 269. 
that had compromised the Ottoman sultan's sovereignty, as his Muslim subjects clamored for the same rights as the dhimmis. ${ }^{53}$

Native Tunisians' strategies to benefit from the protectorate's legal pluralism aggravated French worries regarding the influence their rivals exercised through patents of protection. As a result, France required European powers to review their rosters of protégés in 1898; the bey then issued decrees definitively listing the names of persons protected by foreign governments. ${ }^{54}$ Henceforth, only the persons listed would be entitled to the benefits of foreign protection. ${ }^{55}$ With this new principle in place, the resident general could boast, twenty years after the establishment of the protectorate, of France's progress reining in jurisdictional politics: "European protégés have been registered, and the list of them has been officially issued." ${ }^{56}$ Since protected status could not be passed from one generation to the next, the French administration in Tunisia finally stood poised, at the dawn of the twentieth century, to put an end to the politics of protection played by its imperial rivals. Yet France's solution to the problem of protection accorded to Tunisian subjects by other European powers generated a third problem. If France cracked down on protections offered by other states to native Tunisians, it might also have to limit its own. After forcing other European powers to cease issuing new patents of protection, the residency general began "preparing, with regard to Algerians and French protégés, a review of the registry which will allow us to adjust the status of this significant subgroup." 57 As Algerians were legally French nationals, this would prove more difficult.

${ }^{53}$ Dhimmi refers to non-Muslim "peoples of the book" living in Muslim lands. In the eighteenth- and nineteenth-century Ottoman Empire, dhimmis increasingly benefited from foreign patents of protection. On the problems Ottoman rulers faced from Muslims' desire for the same privileges as the dhimmis, see Salahi R. Sonyel, "The Protégé System in the Ottoman Empire," Journal of Islamic Studies 2, no. 1 (1991): 56-66; Inalcik et al., "imtiyāzāt; and June Starr, "When Empires Meet: European Trade and Ottoman Law," in Contested States: Law, Hegemony, and Resistance, ed. Mindie Lazarus-Black and Susan F. Hirsch (London, 1994), 231-51.

${ }^{54}$ Décret du 15 rabia-ettani 1316 (September 1, 1898), portant publication de la liste individuelle des protégés britanniques, italiens et néerlandais, in JTT (1899), 297ff.; Décret du 19 hidjé 1316 (April 29, 1899), portant publication de la liste individuelle des protégés allemands, danois, belges, hellenes, et russes, in JTT (1899), 330ff.

${ }^{55}$ Indeed, on instruction from the resident general, courts soon began using the lists as a basis for their judgments. See, e.g., the case brought by a Monsieur Boublil, who claimed to be a Dutch protégé. Tribunal de Tunis (1ère ch.), November 2, 1898, in RAT (1899); reference made in court findings to September 1, 1898, decree and September 17,1898 , telegram in which the "resident general informed the court that only natives who were registered on this list could claim to status of protégé."

${ }^{56}$ ANT C-18, dr. 2, fol. 85: Résidence Générale, à son excellence M. Delcassé, ministre des Affaires Étrangères. Direction des Affaires politiques, service de la Tunisie, no. 151, a/s musulmans étrangers en Tunisie, March 25, 1901.

${ }^{57}$ Ibid. 
If European protégés' crossing of jurisdictional boundaries raised the question of French rivals' ongoing influence on everyday affairs in the protectorate, the jurisdictional jockeying of Algerian French nationals in Tunisia drew attention to other cracks in France's imperial edifice..$^{58}$ Asked in 1883 whether it was possible in North Africa to have "two contiguous provinces [that are] governed so differently," Paul Cambon had replied "why not?"59 Yet subsequent events showed this confident defense of protectorate rule to be shortsighted, for Cambon had not taken into account the frequent circulation between Tunisia and Algeria of native Jews and Muslims. This had already presented problems for France prior to the establishment of the protectorate. From the mid-1850s, Algerian rebels facing blockades in their own country moved their operations over the border, increasingly bringing Tunisia into the field of Algerian insurrectional politics. ${ }^{60}$ Under these circumstances, it can hardly be coincidental that France sought to control Algerians' access to rights as French nationals in Tunisia beginning in $1855 .{ }^{61}$ After the 1865 Senatus Consulte conferred French nationality - albeit not citizenship—on Muslim Algerians, they were allowed protection in Tunisia as Frenchmen as long as they proved their Algerian origins and had not lost their "esprit de retour." When nationality became inalienable in 1889 , however, the French administration faced a new problem. The 1889 law made it increasingly difficult for the administration to argue that Algerians had "lost" their French nationality by moving to Tunisia. At the very moment French officials endeavored to limit the number of European protégés, the 1889 law threatened to give Algerians unprecedented rights as protected persons in Tunisia. ${ }^{62}$

${ }^{58}$ For an account that emphasizes how legal maneuvering by Algerians helped to forge an Algerian identity, see Julia Clancy-Smith, "Migrations, Legal Pluralism, and Identities: Algerian 'Expatriates' in Colonial Tunisia," in Algeria and France, 18002000: Identity, Memory, Nostalgia, ed. Patricia M. E. Lorcin (Syracuse, NY, 2006), $3-17$.

${ }^{59}$ Letter to Mme Paul Cambon, dated Tunis, November 7, 1883, in Cambon, Correspondance, 195.

${ }^{60}$ Clancy-Smith, Rebel and Saint, 198 and chap. 6.

${ }^{61}$ Decision of ministry of war, September 7, 1855, cited in Circulaire du Ministère des Affaires Étrangères, January 20, 1869, in M. A. deClerq and M. C. deVallat, Formulaire des chancelleries diplomatiques et consulaires, suivi du tarif des chancelleries et du texte des principales lois ordonnances, circulaires et instructions ministérielles relatives aux consulats; publié sous les auspices du Ministère des affaires étrangères, vol. 2 (Paris, 1909). See also Maurice Chenel, La Medjba: Impôt de Capitation Tunisien (Tunis, 1912), 38. This turning point in policy toward Algerians in Tunisia is also highlighted in Clancy-Smith, "Migrations, Legal Pluralism, and Identities," 7.

62 The advent of the 1889 law also created new problems for Algerian administrators confronted with Tunisians and Moroccans living in Algeria. See Laure Blévis, "La citoyenneté française au miroir de la colonisation: Étude des demandes de naturalisa- 
Chief among the rights Algerians tried to claim was exemption from Tunisian taxes. Among the many taxes levied by the bey, the most vilified was the majba, a head tax requiring all men who had reached puberty to pay at the same rate, regardless of income or wealth. Europeans, residents of Tunisia's major cities, military personnel, and some religious officials were exempt. Algerians, as French nationals, tried to claim the European exemption, a strategy that worked frequently enough to be deemed a major fiscal problem after the establishment of the protectorate. As early as January 1886, France's resident general in Tunisia instructed qaids to require Algerians to pay the majba unless they had valid certificates of French nationality. Passports and travel papers were considered insufficient, while nationality papers held by persons who had owned property in Tunisia since before the French conquest were particularly suspect, very likely belonging to persons who "passed themselves off as Algerian, when in fact they originate from Tunisia." 63 Most tellingly, no person who had paid the majba once would be allowed to obtain a French nationality certificate. This policy assumed that anyone having once paid the majba regarded himself as a subject of the bey, but this was hardly a given. Qaids earned their income by adding a 10 percent fee (majoration) to all collections; it was therefore in their interest to force as many individuals as possible to pay, whether or not they were legally obligated. ${ }^{64}$ Those who did not pay the tax were often threatened with detention or forced to pay a bribe. ${ }^{65}$

tion des 'sujets français' en Algérie coloniale," Genéses 53 (December 2003): 32-35; and Kamel Kateb, Européens, "Indigènes" et Juifs en Algérie (1830-1962), Représentations et réalités des populations (Paris, 2001), 162ff. On the 1889 law more generally, see Patrick Weil, Qu'est-ce qu'un Français? Histoire de la nationalité française depuis la Révolution (Paris, 2002).

${ }^{63}$ ANT C-18, dr. 3, fol. 9: "Circulaire aux Caids," January 20, 1886. Passports were considered insufficient testaments to nationality in other parts of North Africa as well. See Will Hanley, "Foreignness and Localness in Alexandria, 1880-1914" (PhD diss., Princeton University, 2007), esp. 234-65. Hanley points out that nineteenth-century passports were often less permanent documents than today's passports-they were frequently issued for each leg of a trip, and a single person could have several. Thus, authorities in Egypt often considered them the "weakest evidence of nationality, and this was true throughout the Mediterranean" (248).

${ }^{64}$ Richard Alan Macken, "The Indigenous Reaction to the French Protectorate in Tunisia, 1881-1900" (PhD diss., Princeton University, 1973), 153-61; Chenel, La Medjba; Noureddine Dougui, "La politique fiscale du protectorat français en Tunisie (1884-1939)," Revue d'Histoire Maghrébine 81-82 (June 1996): 183-200.

${ }_{65}$ ANT C-18, dr. 3: Vice consulat de France et arrondissement de controle de Gafsa, no. 718 , June 1, 1886, reporting on legitimate Algerians paying up to 20 piastres to qaids in order to avoid the majba of 45 piastres. See also Macken, "Indigenous Reaction," 153, where he notes that it was "not uncommon for a Tunisian to have to pay his majba two or three times before finally obtaining his receipt." 
Whatever efforts were made to force real or alleged Algerians to pay the majba, the finance administration was still dissatisfied a decade later: "This tolerance is bad because there is no real reason that our Algerian subjects should have more advantages ... than our Tunisian protégés, who are no less worthy." ${ }^{66}$ Of course, the finance minister was also worried about the bottom line-in 1896 the majba represented about 18 percent of the Regency's revenues. ${ }^{67}$ Since he endeavored to meet the budget without instituting new taxes, the only means of increasing receipts was to adopt a "draconian discipline" in collection practices. ${ }^{68}$

Court cases brought by defendants claiming Algerian legal status highlighted the importance of tax collection, as well as the problem that Algerians' French nationality posed to the protectorate administration. In one case of this kind from 1899, the plaintiffs, Mohamed ben Amor ben Hamda and his sons, sued the Tunisian government for 50,000 francs in damages after they were coercively detained for failing to pay the majba. The court reasoned that the detention was legal because the plaintiffs had not sufficiently established their Algerian origins. Signaling its desire to establish legal precedent, the court wrote that a "large number of Algerian Muslims" live in the Regency and "do not differ from Tunisian Muslims by their social status or mores." These Algerians "invoke their nationality in order to evade actions taken by Tunisian authorities to enforce the payment of taxes on natives," and this situation "presents drawbacks" of a very serious kind "because the disciplinary legislation to which Algerians are subjected in their own country does not apply to them in Tunisia." The protectorate had tried to end these "abuses" by requiring definitive proof of nationality. ${ }^{69} \mathrm{In}$ fact, a circular from the previous year had instructed civil controllers to verify the status of alleged Algerians, and it was this policy that had triggered the present dispute..$^{70}$ In using Ben Amor ben Hamda's case to establish jurisprudence with regard to alleged Algerians, the court violated the civil-law tradition in which the role of the judge was merely to enforce—not make- the law. At the same time, it sought to place bound-

${ }^{66}$ ANT C-18, dr. 2, fol. 49: Régence de Tunis, Finances, Direction Générale, Note pour M. le Résident Général, June 5, 1895, signed Directeur de Finances Ducroquet. See also complaint generating this response, fol. 48: Petition to M. René Millet, Résident Général de la France en Tunisie, May 20, 1895.

${ }^{67}$ Dougui, "La politique fiscale," 187.

${ }^{68}$ Ibid., 183-200.

${ }^{69}$ Mohamed ben Amor et al. c. Le Contrôleur Civil de Souk-el-Arba, le caïd de Djendouba, et le Gouvernement Tunisien, Tribunal de lère instance de Tunis (1ère chambre), June 14, 1899, in JTT (1900), 367, 364-69. An identical transcript is in RAT (1900), pt. 2:410. Interestingly, similar problems with would-be Algerians develop in preprotectorate Morocco at around the same time. See Bowie, "Aspect."

${ }^{70}$ On the December 5, 1891, circular, see ANT C-18, dr. 1, fol. 14: Extrait du rapport trimestriel de M. le Contrôleur Civil de Tozeur (4e trimestre 1892). 
aries on the status of persons whose social and legal strategies had long defied such rigid categorizations.

Acknowledging that the plaintiffs did "appear to be of Kabyle [and thus Algerian] origin," the court nonetheless emphasized that the father had lived in Tunisia for many years. ${ }^{71}$ Since he had arrived in Tunisia before the French conquest, the court reasoned, the family must have "left Algeria to flee French domination and in so doing, had repudiated their country of origin." 72 Having left Algeria with no apparent intention of returning, they had renounced their French status. The fact that the French nationality law of 1889 made renunciation impossible was of no consequence, since they had allegedly done so before the law had passed. Their presentation of a "deed of notoriety" in which witnesses from the commune mixte of Haut-Sébaou attested to Ben Amor ben Hamda's Algerian origins was "all the more suspect since the witnesses whose declarations it contains testify to very old events and claim to know well persons who left the country thirty years ago." 73 The court already had concluded in an earlier case evidently pertaining to the same family that "the absence of a desire to return should be presumed more readily with regard to a simple subject as opposed to a citizen, especially in the case of a Muslim establishing himself in a Muslim country." 74 Subsequent cases repeatedly reasoned that "Muslim natives domiciled in Tunisia must be considered Tunisian subjects, unless proved otherwise." 75 With regard to Jews, who unlike Muslims became full-fledged citizens in Algeria by virtue of the 1870 Crémieux decree, Tunisian courts generally made similar determinations, sometimes going so far as to suggest that the individual concernedeven when able to establish Algerian origins-could not benefit from the Crémieux decree unless he or she had explicitly filed for recognition as a citizen. In one notorious case, a justice of the peace in Tunis ruled against a Jewish man's claim of French status, editorializing that "nothing is more shocking" than Jews who had lived in Tunisia "a quarter of a century or more," and who differed in no way from Tunisian Jews, making use of their Algerian origins only in order to "thwart the action of local authorities." This

${ }^{71}$ Kabylia is a region in Algeria.

${ }^{72}$ Mohamed ben Amor et al. c. Le Coutrôleur Civil de Souk-el-Arba, in JTT (1900), 367; RAT (1900), pt. 2:410.

${ }^{73}$ Ibid.

${ }^{74}$ Ministère public c. Mohamed ben Amor et al., Tribunal de Tunis (1ère chambre), December 2, 1891, in RAT (1892), pt. 2:144.

${ }^{75}$ Consorts Souissi c. Kazri et Ben Saad, Tribunal de Tunis (1ère chambre), March 14, 1892, in RAT (1892), pt. 2:243-45. For similar judgments, see, among others, Mansour c. Deldoul, Tribunal de Sousse, May 9, 1889, in RAT (1889), pt. 2:539-39; Khasnadar c. Ben Merzouk, Tribunal de Tunis (1ère chambre), January 11, 1897, in RAT (1898), pt. 2:247-48; Ben Saïd c. Habitat, January 29, 1902, Tribunal de Tunis (1ère chambre), in RAT (1903), pt. 2:23-26. 
judgment, and later cases following the same line of reasoning, infuriated the editor of the law journal in which they were reprinted. "Indigeneity is a fact," Émile Larcher wrote in the footnote to this case. "If birth in Tunisia is a presumption of Tunisian nationality, why wouldn't birth in Algeria be proof of French nationality?"'76

The court's argument in the Ben Amor ben Hamda case was legal camouflage. The issue was neither why one individual, Mohamed ben Amor ben Hamda, had left Algeria nor what impact this had on his nationality and that of his family. The question was a far more general one arising from the clash of the different forms of colonial rule France had adopted in Tunisia and Algeria. As long as France maintained that Tunisia was a foreign territory, then it was obliged - at least in theory-to provide consular protection to all French nationals, including Algerians, living in Tunisia. Yet this very pretense threatened to undermine the subjected status of Algerians. Equally important, it called into question the strict jurisdictional separation that French resident generals, in the name of honoring the bey's sovereignty over his subjects, had established between "natives" and "Europeans." After all, as the court had reasoned in an earlier case, "French jurisdiction was instituted in Tunisia in order to judge cases pertaining to Europeans." ${ }^{77}$ The court could not very well concede that the categories of "European" and "Tunisian" overlapped, because doing so would have undermined the entire premise of colonial domination, which posited a hierarchical and incommensurable relationship between European and native laws. ${ }^{78}$ Instead, French courts in Tunisia increasingly used religious affiliation as a proxy for nationality, even when

${ }^{76}$ Boukhris c. Cattan et Gallula, Justice of the Peace, Tunis-Northern Canton, January 20, 1905, in RAT (1905), pt. 2:212-16, including note by Émile Larcher. For similar cases, see, among others, Consorts Escheriffat c. Enriquez, Tribunal de Tunis (1ère chambre), May 23, 1893, in RAT (1893), pt. 2:385-87; Liscia c. Giami, Tribunal de Tunis (1ère chambre), February 24, 1904, in RAT (1904), pt. 2:215-16; Sauveur Sitbon dit Beyda, Tribunal de Tunis (chambre de conseil), June 6, 1906, in RAT (1907), pt. 2:202-5. For an exception to this trend, see Jacob et Aron Sitbon c. Scialom Sitbon, Algiers Appeals Court (1ère chambre), December 14, 1905, in RAT (1907), pt. 2:91-95. Larcher found the Sitbon c. Sitbon case particularly important given the "rather considerable number of Israelites who, in Tunisia, take advantage of their Algerian origin, and thus their French status, in order to avoid certain taxes and in order to fall under the jurisdiction of French courts" (Larcher in Sitbon c. Sitbon, 91, n. 1). The Algiers Appeals Court ruled in the entirely opposite sense, however, in a subsequent case, Tibika c. dame Tibika, Algiers Appeals Court (1ère chambre), June 7, 1906, in RAT (1907), pt. 2:128-35.

${ }^{77}$ Consorts Souissi c. Kazri et Ben Saad, Tribunal de Tunis (1ère chambre), March 14, 1892, in RAT (1892), pt. 2:245.

${ }^{78}$ On this relationship more generally, see Emmanuelle Saada, "Citoyens et sujets," and "The History of Lessons: Law and Power in Modern Empires," in Lessons of Empire: Imperial Histories and American Power, ed. Craig Calhoun, Frederick Cooper, and Kevin W. Moore (New York, 2006), 34-47. 
doing so meant contradicting France's policies in neighboring Algeria. ${ }^{79}$ Decisions such as these had symbolic value, as well as real-world consequences - witness the incarceration of Ben Amor ben Hamda and his sons. French authorities had an ideological interest in portraying the native legal status as inferior to their own-as something Tunisians would want to escape. Nonetheless, in order to maintain the fiction of the bey's sovereignty and uphold the notion of European superiority, they also had to protect the line dividing "Europeans" from "natives." Over the next several years, courts became the principal defenders of this distinction, sometimes establishing "excessively difficult" conditions by blocking as "intruders those who wish to enter into their court." ${ }^{80}$ Despite this defense of jurisdictional boundaries, Tunisia's legal pluralism continued to present challenges to France's pursuit of dominance in the Mediterranean region in the twentieth century.

\section{BORDER CROSSINGS}

Movement across borders within the French empire called into question the legal boundaries French authorities wished to draw between populations in Tunisia. The porous border with Algeria had always presented this sort of problem. ${ }^{81}$ But as France extended its imperial reach in Africa at the turn of the century, the consolidation of rule in one place contributed to new legal complications in another. In 1895, France established the Federation of French West Africa (Afrique Occidentale Française, or AOF), and in 1902, it completed its "pacification" of the Algerian Sahara, incorporating it as the "territories of the south." 82 Although these territorial appropriations solidified

${ }^{79}$ In practice, religion also served as a "proxy" for a racial or ethnic understanding of legal status in Algeria, despite its legal incorporation into French territory. For instance, Muslims who converted to Christianity in Algeria were still subjected to the Islamic civil status and remained barred from full citizenship. For historian Laure Blévis, this signifies that "the term 'Muslim' did not merely designate the religion of Muslim natives. It also corresponded to a status (état), a social condition viewed as a fundamental alterity, more so than as confessional practice" (Laure Blévis, "Les avatars de la citoyenneté en Algérie coloniale ou les paradoxes d'une catégorisation," Droit et société 48 (2001): 577, 557-80). Since judges in Tunisia were all trained in or for Algerian courts, they likely held similar views.

${ }^{80}$ Unsigned editorial footnote, Zeneikha bent Hasin c. Mohamed ben el Hadj Amor, Tribunal de Tunis (2e chambre), October 18, 1905, in RAT, pt. 2:208 n. 1.

${ }^{81}$ On the porousness of that border, see Clancy-Smith, Rebel and Saint, passim.

${ }^{82}$ On the conquest of the western Sudan, see A. S. Kanya-Forstner, The Conquest of the Western Sudan: A Study in French Military Imperialism (Cambridge, 1969); Michael Crowder, West Africa under Colonial Rule (London, 1968); J. D. Hargreaves, "The European Partition of West Africa," and C. Harrison, T. B. Ingawa, and S. M. Martin, "The Establishment of Colonial Rule in West Africa c. 1900-1914," in History of West Africa, ed. J. F. A. Ajayi and Michael Crowder, vol. 2, 2nd ed. (London, 1974). 
France's position in North and West Africa, they were socially disruptive. "Pacification"- a euphemism for consolidating conquest through forceinevitably displaced populations. Moreover, in the western Sudan, the establishment of French rule meant that slavery lost its legal standing; this in turn rent local social relations, as former slaves took leave of their masters and migrated in search of work as free laborers, trying to evade their former masters' efforts to find new legal means for forcing their return. ${ }^{83}$ Eager for low-cost labor, farms and mining concerns in Tunisia welcomed migrants displaced by the expansion of France's empire to its southwest.

Like Algerians before them, migrants from the western Sudan arriving in Tunisia made the most of France's territorial acquisitions by demanding protection as "French subjects." ${ }^{44}$ Faced with these new demands, administrators in Tunisia found themselves downplaying France's recent triumphs in the AOF, arguing instead that French authority was "much less effective" in its Sudanese colony than in the Tunisian protectorate.$^{85}$ It would be perverse, they thought, to offer AOF migrants protection that they were unwilling to give Tunisians. Seeking a legal rationale for this argument, they maintained that there was no law pertaining to the Sudanese that was "analogous" to the Algerian Senatus Consulte. With no legal basis for claiming nationality, the procureur de la république (attorney general) argued, the Sudanese could not be considered French nationals in Tunisia. ${ }^{86}$ Nor, exactly, were they foreigners. Instead, jurists for the protectorate claimed that Muslim subjects, regardless of geographic origin, owed allegiance to the bey-a Muslim sovereign ${ }^{87}$

Protectorate authorities' assertion that Muslims were not nationals anywhere- only subjects—claimed to be respectful of Islamic law. The argu-

On the southern territories of Algeria, see Gouvernement Général de l'Algérie, Les territoires du sud de l'Algérie, exposé de leur situation, publié par l'ordre de M. Steeg, Gouverneur Général de l'Algérie (Alger, 1922); René Victor Vâlet, Le Sahara Algérien: Étude de l'organisation administrative, financière et judiciaire des territoires du sud (Alger, 1927).

${ }^{83}$ Roberts, Litigants, chap. 4.

${ }^{84}$ ANT C-18, dr. 2, fol. 85: Résidence Générale, à son excellence M. Delcassé, ministre des Affaires Étrangères, Direction des Affaires politiques, service de la Tunisie, no. 151, a/s musulmans étrangers en Tunisie, March 25, 1901.

${ }^{85}$ ANT C-18, dr. 2, fol. 111: Monsieur Benoit, Résident Général par interim à Monsieur Spire, procureur de la république à Tunis, no. 1326, a/s de la situation en Tunisie des indigènes originaires des centres africains soumis à l'influence française, March 22, 1901.

${ }^{86}$ ANT C-18, dr. 2, fol. 111: Parquet du Procureur de la République, April 3, 1901.

${ }^{87}$ ANT SG5 C-63, dr. 2: Gouvernement tunisien, Secrétariat Général, Section d'État, compétence des tribunaux français à l'égard des sujets musulmans, no. SD 51, February 7, 1902. If any of the migrating Sudanese were non-Muslims, authorities did not address this fact. 
ment was also convenient. It demonstrated that recognizing the bey's sovereignty did not always constrain French power; sometimes, doing so helped maintain a colonial civic order that relegated Muslims and Jews to an unequal status. Where did this opportunistic understanding of Islamic law leave Algerians? As French nationals, they were an anomaly. But even in their regard, new efforts were made to curb alleged fraud and bring them under the umbrella of the bey's sovereignty. Writing to Algeria's governor general Charles Jonnart in 1903, Resident General Stéphen Pichon complained that he had already called to Jonnart's attention the "ease" with which Tunisian natives "conniv[ed]" to obtain Algerian papers. Now he was asking that Algerian local officials contact Tunisian civil controllers to verify the status of any resident of Tunisia who filed a request for a deed of notoriety establishing Algerian origins. ${ }^{88}$ For all Cambon had celebrated the fact that Algeria and Tunisia were "two contiguous provinces governed so differently" in $1883,{ }^{89}$ twenty years later the administration of one came to require the cooperation of the other.

Yet the real difficulties came with the shift of Mediterranean politics in the 1910s, in the wake of the Agadir Crisis in Morocco and Italy's invasion of Libya in 1911. Following the Italian invasion, many Libyans fled the ItaloTurkish war, crossing the border into Tunisia. In the fall of 1912, Italy amnestied the fugitives and promised them protection if they returned. ${ }^{90}$ After Italy annexed Libya as two colonies-Tripolitania and Cyrenaica-it demanded that its new subjects be treated as Italian protégés in Tunisia. This led Pichon, now the French minister of foreign affairs, to protest that France's "recognition of the annexation of Libya does not at all imply that all natives originally from this territory who are established in Tunisia have acquired, as far as the government of the Republic is concerned, the status of Italian subjects, nor that Italy's new colonial subjects (sudditi) have the right to demand in the Regency the same treatment as Italians (cittadini)." 91 Although

${ }^{88}$ ANT E 507, dr. 2: Le Résident Général de la République Française à Tunis à Monsieur Jonnart, Gouverneur Général d l'Algérie, no. 3437, November 3, 1903.

${ }^{89}$ See n. 59 above.

${ }^{90}$ ANT A 280, dr. 9, sd. (subdossier) 13, fol. 28: Proclamation of November 16, 1912, referenced in ANT A 280, dr. 9, sd. 13, note sur la question des Tripolitains en Tunisie (n.d. [1913 or later]). Also ANT A 280, dr. 9, sd. 20, fol. 47: Proclamation issued October 4, 1913, inviting Libyans to return and amnestying them for war participation. See also fol. 58, Délégué à la Résidence Générale à M. Stéphen Pichon, Ministre des Affaires étrangères, no. 739, October 9, 1913, on the profound effect of the proclamation.

${ }^{91}$ ANT A 280, dr. 9, sd. 4: M. Stéphen Pichon, Ministre des Affaires Étrangères à M. le Résident Général de la République Française, December 6, 1913. Italian in original. 
Italy had considerable trouble establishing effective rule in Libya,,${ }^{92}$ it nonetheless managed to use its annexation of Tripolitania and Cyrenaica to leverage its bargaining power in Tunisia. Ingeniously, the Italian government drew a direct parallel between Libyans and Algerians. Just as the latter were nationals, but not full citizens, of France, so too had Libyans become Italian nationals. The fact that they did not have the same rights as Italian cittadini was, according to the Italian government, immaterial since Algerians were entitled to special protection as nationals while living in Tunisia although they too were not citizens. ${ }^{93}$ As the French and Italian foreign ministries sparred on this front, France finally established a protectorate over most of Morocco in 1912, save for the Spanish zone and the port city of Tangier, which retained a separate status. The coincidence of the Moroccan and Libyan crises led to at least two major changes in the Tunisian civic order: the discontinuation of the onerous majba and the institution of a new legal category-the "Tunisian nationality"- to which all native Muslims and Jews were to belong.

The bey's subjects had long maneuvered within the country's multiple jurisdictions as they sought to maximize their own interests. While a crackdown on this behavior at the end of the nineteenth century had foreclosed the possibility of claiming formal protection by foreign governments, and made invoking Algerian origins a risky gamble, the advent of the Italian annexation of Libya provided a new opportunity to evade local jurisdictions-particularly for Tunisians living in the east and southeast. This development threatened French authority in Tunisia much more than had foreign patents of protection. Patents, after all, had required annual purchase and were subject to renewal. Nationality, however, was ordinarily permanent. Crucial to the new threat was its social impact. Had Tunisian subjects seen no benefit in claiming to be Libyan, France would have had little reason to oppose the Italian measures.

The social impact of the Italian strategy was soon obvious. Report after report from the French civil controllers, the resident general's local representatives, recounted cases of persons who had long been considered Tunisian suddenly claiming to be Italian protégés. These new supposed sudditi claimed exemption from the majba, regained fishing rights along the Libyan coast (where Tunisians had fished for ages and now saw their livelihoods cut off by Italy's closure of the coastline to foreign boats), attempted to have their civil

92 Giambattista Biasutti, La politica indigena italiana in Libia: Dall'occupazione al termine del governatorato di Italo Balbo (1911-1940) (Pavia, 2004); Lisa Anderson, The State and Social Transformation in Tunisia and Libya, 1830-1980 (Princeton, NJ, 1987), 179-221.

${ }_{93}$ ANT A 280, dr. 9, sd. 13: Note sur la situation des Tripolitains en Tunisie (n.d. [1913]); Ministère des Affaires Étrangères, Direction des Affaires politiques et commerciales, Note, April 23, 1913; Ministère des Affaires Étrangères, Direction des Affaires politiques et commerciales, M. de Billy to M. Pichon, no. 299, Rome, August 19, 1913. 
disputes heard in French courts, and, local officials feared, might also claim exemption from military service. ${ }^{94}$ As the qaid in Cap Bon urgently reminded the general secretary of the Tunisian government in the fall of 1913, some 50 percent of Cap Bon natives had paid to be replaced when called for military service during the conquest of Morocco: "If we open the door to Italian subjecthood to them, they will see in it a way out of the majba and military service." Already in his region, a prominent local notable had obtained Italian protection. Turning alarmist, he predicted that these new subjects could become the "avant-garde of an Italian occupation army." 95

French authorities in Tunis dismissed rumors of Italian invasion plots as just that-rumors. But they nonetheless were deeply concerned that Italy's demands would "compromise the very operation of the Protectorate." 96 If Italy were to succeed in securing the right for Libyans to fall under European jurisdiction, a French memo opined, this would have "disastrous consequences for our prestige in Tunisia," for Tunisians would not accept "without bitterness a situation where they found themselves inferior to Italian subjects." ${ }^{97}$ In particular, French officials opposed Italy's proposal to backdate the Italian nationality of Libyan subjects to 1881. This would "render futile" all France's efforts to "achieve order out of chaos" in the Regency. ${ }^{98}$ Backdating nationality would bring the number of Libyans living in the Regency, estimated as ranging from 20,000 to 50,000 to some ten times that-far exceeding the present numbers of Italians $(88,000-113,000)$ and French $(46,000)$ combined. ${ }^{99}$ Such demands for recognition of nationality would be the source of

${ }^{94}$ A partial list follows. All are from ANT A 280, dr. 9. Sd. 3: Contrôleur Civil de Béja, no. 1264, October 23, 1912; Consolato generale di S. M. il Re d'Italia, November 19, 1912; Contrôleur Civil de Sousse, no. 465, January 21, 1913; Contrôleur Civil de Sfax, October 9, 1913; Contrôleur Civil de Sfax, no. 1598, April 29, 1914. Sd. 5: Consolato Generale di S. M. il Re d'Italia, April 19, 1913. Sd. 10: Contrôleur Civil de Sousse, marked confidential, no. 4573, August 27, 1913; Caidat des Soussi to Contrôleur Civil de Sousse, September 8, 1913. Sd. 11: Telegram, Contrôleur Civil de Sfax à la Résidence Générale, October 29, 1913. Sd. 12: Caïd du Cap Bon, October 6, 1913; Contrôleur Civil de Grombalia, September 29, 1913. Sd. 20: Telegram, Délégué Résidence Générale à Affaires Étrangères, no. 131, September 10, 1913; le Délégué à la Résidence Générale à M. Dubourdieu, Directeur général des finances, no. 6041, Tunis, October 24, 1913; Contrôleur Civil de Gabès à M. Alapetite, Ministre Plénipotentiaire, Résident Général de la République Française, no. 2438, Gabès, October $31,1913$.

${ }^{95}$ ANT A 280, dr. 9, sd. 12: Caïd du Cap Bon, October 6, 1913.

96 ANT A 280, dr. 9, sd. 13: M. Pichon, Ministre des Affaires Étrangères, à M. de Billy, chargé d'affaires de la République Française à Rome, June 30, 1913, a.s. de la situation des Tripolitains en Tunisie, 2.

${ }^{97}$ ANT A 280, dr. 9, sd. 13: Note sur la situation des Tripolitains en Tunisie (n.d. [1913]).

${ }^{98}$ Ibid.

${ }^{99}$ The French census of 1911 recorded 46,054 French nationals and 88,182 Italian 
"constant troubles"; the number of cases to be tried before French penal courts would "more than double," as would the need for justices of the peace. This would, the French foreign minister claimed, pervert the objectives of the French justice system, which had been established to satisfy the "Europeans." 100 For this very reason, not to mention the costs it would have entailed, the protectorate administration already had rejected a push from French jurists and Tunisia's Jewish community, following the discontinuation of foreign protection, to extend the French justice system to native subjects. ${ }^{101}$ There were other costs to the Italian demands. Libyans' exemption from the majba would have the most "unfortunate impact on our native populations," for it

nationals. However, records of official declarations of foreigners in December 1913 showed 112,982 Italians; this number increased to 116,856 by December 1914. For both sets of figures, see Régence de Tunis, Protectorat Français, Direction Générale de l'Agriculture, du Commerce et de la Colonisation, Statistique générale de la Tunisie, année 1914 (Tunis, 1915), 6, 28. Stephen Roberts estimates that the 1911 census undercounted the Italian presence by as much as half and overestimated the French presence by several thousand. See Roberts, The History of French Colonial Policy, 1870-1925 (London, 1929), 1:286. See also Helen Broughall Metcalf, "The Problem of Tunisia in Franco-Italian Relations, 1835-1938" (PhD diss., University of Maryland, 1942), 500-506. For the Libyan figures, see ANT A 280, dr. 9, sd. 13: Note sur la situation des Tripolitains en Tunisie (n.d. [1913]); Note, Ministère des Affaires Étrangères, Direction des Affaires politiques et commerciales, April 23, 1913; Ministre des Affaires Étrangères à M. de Billy, chargé d'affaires de la République française à Rome, August 9, 1913. ANT A 280, dr. 9, sd. 14: Note sur la première proposition dated May 5, 1913.

100 ANT A 280, dr. 9, sd. 13: "Difficultés constantes"-Ministre des Affaires Étrangères à M. de Billy, chargé d'affaires de la République française à Rome, August 9, 1913; "Plus que double"-ANT A 280, dr. 9, sd. 14: Note sur la première proposition dated May 5, 1913. On the courts being designed for Europeans-ANT A 280, dr. 9, sd. 13: Note, Ministere des Affaires Étrangères, Direction des Affaires politiques et commerciales, April 23, 1913.

101 ANT E 144, dr. 7, sd. 1: Mémoire pour servir à l'extension de la Justice Française en Tunisie, Par les avocats du barreau de Tunis (Tunis: Imprimerie Rapide, 1898); Observations sur le mémoire pour servir à l'extension de la Justice Française en Tunisie, Par un avocat français inscrit au barreau de Tunis (Tunis, 1899); undated note responding to mémoire; M. Millet, Résident Général à S. E. Mr Delcassé, ministre des AE, Direction politique, Sous-direction du Midi, no. 22, January 14, 1899 (including references to higher cost of the French judicial system compared to the native Tunisian system); Ministère des Affaires Étrangères, Direction des Affaires politiques, sousdirection du Midi, February 10, 1899; "Les Israélites de Tunisie et les Tribunaux Français," Dépêche Tunisienne, February 16, 1899; ANT E 144, dr. 7, sd. 2: H. de Lamothe, "Les revendications des israélites tunisiens," La Presse Coloniale, December 31, 1907; undated note "au sujet de la naturalisation des indigènes tunisiens"; undated and untitled handwritten note on jurisdictional questions for Jewish Tunisians; Gouvernement Tunisien, Direction des Services judiciaires, Cabinet, "Arguments complémentaires Page 14, alinea 2" (n.d.). 
would "make our power in Tunisia appear questionable," as Italy would have succeeded in exonerating its own subjects from taxes owed the bey while France would not have been able to do the same for its own charges. ${ }^{102}$ The Italian maneuvers were designed to engineer a power struggle that would quickly place the French government "in the position of either abdicating or reacting with a show of brute force like annexation." 103 For all these reasons, France had a "vital interest" in not succumbing to Italian demands. ${ }^{104}$

French officials did succeed in negotiating an agreement with Italy setting October 28, 1912, the date of French recognition of Libya's annexation, as the base date for considering Libyans Italian subjects. ${ }^{105}$ But this small victory came at a price. Italy's constant complaints about its subjects being forced to pay the majba, and the growing numbers of persons hitherto considering themselves Tunisian who sought Italian status for their personal benefit, led the protectorate to institute taxation reforms. The inegalitarian majba was finally abolished and replaced with a new tax — the istitan — which required all adult males who had lived for three continuous months in Tunisia, regardless of nationality, to pay ten francs annually. ${ }^{106}$ The idea for this reform was not new; Tunisian members of the consultative council had pushed its institution for several years already. ${ }^{107}$ But, despite growing opposition from Tunisians to inequities such as the majba, the settler lobby had always succeeded in blocking the change and retaining Europeans' privileged tax situation. ${ }^{108}$ The tax burden was only equalized when, as the senior member of the consultative council's French section, the polemicist Victor de Carnières, admitted after-

102 ANT A 280, dr. 9, sd. 14: Note sur la troisième proposition dated May 5, 1913.

${ }^{103}$ ANT A 280, dr. 9, sd. 20: Le Délégué à la Résidence Générale, à M. Stéphen Pichon, Ministre des Affaires Étrangères, no. 656, au sujet des tripolitains, September 7, 1913.

104 ANT A 280, dr. 9, sd. 13: "Intérêt majeure"-Note sur la situation des Tripolitains en Tunisie (n.d. [1913]).

${ }^{105}$ Convention of May 29, 1914, in ANT A 280, dr. 9, sd. 4, fol. 28.

106 Taoufik Ayadi, Mouvement réformiste et mouvements populaires à Tunis (19061912) (Tunis, 1986), 113-28, 256-60; Dougui, "La politique fiscale," 196.

${ }^{107}$ See esp. AMAE, Correspondence politique et commerciale (CPC) Nouvelle série, Tunisie 431: Procès-Verbaux, Conférence Consultative, November 27, 1909, and December 1, 1909.

${ }^{108}$ In 1912, a massive boycott of the Tunis tramway system by Muslims, although triggered by the accidental killing of a Muslim child by an Italian driver, quickly made equal rights demands (tram salaries and treatment of passengers) the center of its campaign. See esp. Eqbal Ahmad and Stuart Schaar, "M'Hamed Ali: Tunisian Labor Organizer," in Struggle and Survival in the Modern Middle East, ed. Edmund Burke III (Berkeley, 1993), 191-210. Frustration with the French administration had been growing for months since November 1911, when French authorities had responded to violent unrest (triggered by rumors that the French administration intended to expropriate land belonging to the Muslim Jellaz cemetery in the Tunis outskirts) with severe repression. 
ward, "the suppression of the majba was voted by the French for reasons of foreign policy and not out of solicitude for the natives." 109 What de Carnières left out, of course, was that the two had become inseparable. It was because this decision implicated both foreign and domestic policy that the Residency applauded the council's French members for "patriotically renouncing their own privilege in order to remove a danger that seemed difficult to settle via diplomacy." 110

The "reasons of foreign policy" invoked by de Carnières were primarily France's ongoing negotiations with Italy over the base date for the Italian subjecthood of Libyans. But there was another dispute also brewing-with Great Britain. The Affair of the False Maltese erupted in November 1913 when Tunis police discovered that a man purporting to be a rabbi, Nessim Haïoune, had developed an ingenious scheme whereby native Tunisians could acquire Maltese birth certificates. In exchange for a significant fee, Haïoune would help them secure the certificates, with which they could claim British nationality. Covered widely in the press, the affair quickly became a cause célèbre, as newspapers sympathetic to Haïoune decried the dual justice system that the scandal called into question. ${ }^{11}$ As with the situation created by Italy's annexation of Libya, the Affair of the False Maltese was regarded as "detrimental to France's influence." 112 At a minimum, it strained France's relations with Great Britain, which felt obliged to regard the "false Maltese" as its subjects pending completion of Malta's inquiry into the possible complicity of

109 Victor de Carnières, November 30, 1913, cited in Ayadi, Mouvement réformiste, 258.

110 ANT A 280, dr. 9, sd. 13, fol. 28: Note sur la question des Tripolitains en Tunisie (n.d. [late 1913 or early 1914]), 4.

111 "Pour Échapper à la justice indigéne," La Tunisie Française, November 22, 1913; "Faux Papiers Fausses Nationalités: Où l'on voit des Tunisiens transformés en étrangers," La Dépêche Tunisienne, November 22, 1913; "Une nationalité abhorrée: Les sujets tunisiens cherchent, par n'importe quel moyen, à se débarrasser de leur nationalité. Les scandales se multiplient. Et ce sera toujours ainsi tant qu'on n'aura pas aboli les juridictions indigènes. La suppression de la Medjba appelle celle des passeports, de la Driba et de l'Ouzara," La Petite Tunisie, November 26, 1913; "Pour se soustraire à la justice indigène," La Tunisie Française, November 24, 1913; "Arrestation arbitraire," La Justice, November 25, 1913; "Encore l'affaire des certificats de nationalité," La Tunisie Française, November 27, 1913; “A l'Instruction: L'affaire des Faux Maltais: Le juge d'instruction inculpe les témoins. 18 arrestations sont opérées," La Dépêche Tunisienne, June 16, 1914; "A l'instruction: L'affaire des faux maltais. Formalités judiciaires-Au Service anthropométrique-mises en liberté sous caution-pauvre Haioun!" La Dépêche Tunisienne, June 17, 1914.

112 "Pour Échapper à la justice indigène," La Tunisie Française, November 22, 1913. 
its public servants in producing what were-whether obtained on false pretenses or not-authentically issued documents. ${ }^{113}$

To the Libyan and Maltese affairs was added another complication: Morocco. France's establishment of a protectorate over Morocco with the Treaty of Fez (March 30, 1912) allowed it to control the entire Maghrib and also very nearly to link its North African and West African empires-a major feather in France's imperial cap. But even more than the conquest of Tunisia, France's position in Morocco depended on placating international interests. This situation-as much as the oft-mentioned "success" of Tunisia as a model-determined France's choice of governance in Morocco. ${ }^{114}$ Like his counterpart the bey in Tunisia, the Moroccan sultan was considered sovereign. But if Tunisia and Morocco were each sovereign, this meant they were foreign to one another. Potentially, a Moroccan in Tunisia could demand French protection abroad, and a Tunisian could claim the same in Morocco. France was committed to maintaining this fiction of sovereignty where it served French interests. When jurists and Tunisian Jews had called for the elimination of the Regency's dual judicial system at the end of the nineteenth century, for instance, French authorities had argued that such a proposition deprived the bey of his subjects and that as such it implied the "overturning, pure and simple ... of the protectorate." 115

With the advent of the Moroccan protectorate, however, this argument became strained: Muslims living in Tunisia would fall under beylical justice unless protected by a foreign power. Surely Moroccans were. If France protected Morocco in the international arena, did it not protect its subjects, as well? An Egyptian court argued this to be precisely the case in $1913 .{ }^{116}$ But French officials concluded in 1914 that decisions like the Egyptian one were "deviations" and, as such, not likely to "modify our viewpoint." Instead, Moroccans were "neither French, nor protégés, in the sense that is given to that word in Tunisia." That status was reserved for holders of patents, a dwindling population since the reforms of 1898. Rather, according to French understanding of Islamic law, Moroccans, like all Muslims, owed allegiance to a Muslim sovereign in whatever country they resided, regardless of whether

${ }^{113}$ See, e.g., the British consul Sir Ernest James Lennox Berkeley's complaint regarding the still-poisoned relationship some four years later. ANT 159, dr. 2, sd. 24: Berkeley to Alapetite, June 12, 1917.

114 On Tunisia as a "successful" model of protectorate rule, see Raymond F. Betts, Assimilation and Association in French Colonial Theory (1960; repr., Lincoln, NE, 2005).

115 ANT E-144, dr. 7, sd. 1: Undated internal memorandum (1898 or 1899).

116 ANT SG 5 C-63, dr. 2: Tribunal mixte du Caire, February 27, 1913, referenced in Protectorat Français de Tunisie, Justice Française, Parquet du Procureur de la République, no. 1468s (19 juillet 1928). 
it was their country of origin. ${ }^{117}$ Moreover, they "had always been treated as natives in Tunisia," a state of affairs the French had no interest in modifying. Amid arguments in the name of Islamic law, rationality, justice, and equity, the careful reader could discern another reason: "This solution ... is indispensable especially from a political point of view." 118 After all, at the time that the memorandum advancing this interpretation was issued, discussions with Italy with regard to Libyans were still under way, and French negotiators surely wanted to avoid a situation where their treatment of Moroccans gave Italy leverage. ${ }^{119}$ Maintaining the legal privileges of Europeans was also important to the residency general's efforts to placate its own settlers, for the conflict with Italy elicited new calls from them to annex Tunisia and, in so doing, end this "bastard regime," as one newspaper editorial put it. ${ }^{120}$

As the consequences of Italy's conquest of Libya, the settlement of the Moroccan question, and the "false Maltese" scandal piled up on one another, French authorities sought new ways to manage Tunisia's jurisdictional complexity. Less than a month after the agreement with Italy, and within days of the Haiioune case being heard by an investigating magistrate, the bey issued a new decree-Tunisia's first nationality law. Aiming to "cut short" the maneuverings of people like Haïoune, the government "took advantage of the events in Tripolitania to issue a decree which was promulgated on June 19, 1914." 121 The decree proclaimed that the following persons were Tunisian nationals: "(1) Any individual residing in Tunisia who does not benefit from

117 ANT SG 5 C-63, dr. 2 f. 124: Internal memorandum, Secrétariat Général du Gouvernement Tunisien, February 5, 1914. Note that officials did not entertain here the status of Moroccan Jews.

118 Ibid.

${ }^{119} \mathrm{In}$ a subsequent period of renegotiating jurisdictional politics in the late 1920s and 1930s, this desire would be made even more explicit. See ANT SG 5 C-63, dr. 2: Protectorat Français de Tunisie, Justice Française, Parquet du Procureur de la République. Le procureur à M. le Ministre, Résident Général de la République Française, no. 1069-s, May 22, 1929; Protectorat Français, Justice tunisienne, Direction des Services judiciaires, Note no. 67 pour M. le Secrétaire Général du Gouvernement Tunisien, January 10, 1934; Secrétariat Général du Gouvernement Tunisien, Service Juridique et de Législation, no. SJL 635, December 17, 1934; Direction des Affaires Politiques et commerciales, Afrique-Levant, Compétence Judiciaire à l'égard des Marocains, le Résident Général de France à Tunis à son excellence M. Pierre Laval, Ministre des Affaires étrangères à Paris, February 2, 1935.

${ }^{120}$ ANT A 280, dr. 9, sd. 19: Édouard de Ballaing, "Pour ou contre l'Annexion," La Tunisie Française, January 5, 1914. See also P. de la Charrière, "Le Seul Remède," Le Journal de Tunis, February 19, 1914; "L'annexion" (interview with Victor de Carnières), Le Colon Français, March 1, 1914; "Pour l'annexion: La condition des Tripolitains," La Tunisie Française, January 15, 1914.

${ }^{121}$ Sousse Civil Court's retrospective accounting of the rationale for the June 19, 1914, degree, in Hassen ben Romdan c. héritiers Romdan ben Romdan, Tribunal de Sousse, June 17, 1915, Jugement, in RAT (1916), pt. 2:47. 
the status of French or foreign citizen or that of French or foreign subject, by virtue of treaties to which the Tunisian government is party; (2) Any individual residing in Tunisia who was born in Tunisia before or after the promulgation of this decree or who was born abroad to a Tunisian father, or, if the father is unknown, to a Tunisian mother." ${ }^{122}$ In an ironic twist, the decree was apparently "inspired by the Italian decree on nationality in Libya." 123 The Italian decree, meanwhile, seemed to take a page from the French rule book, when it declared that "all Muslims residing in Tripolitania and Cyrenaica are presumed Italian subjects until proved otherwise."124 Whatever its inspiration, the June 19 beylical decree broke new ground. First, it asserted that there was such a thing as Tunisian nationality, not just subjecthood to the bey. Second, it reaffirmed the territorial sovereignty of the bey by establishing that any person born in that territory, save for those exempted, would be Tunisian by virtue of the jus soli principle of nationality. In addition, it also asserted a jus sanguinis principle, whereby Tunisian nationality could be conferred by virtue of descent. This clause probably aimed to address the "false Maltese" affair directly: if Haïoune's clients had Tunisian parents, then they too would be Tunisian by birth, regardless of whether they were in fact born in Malta. ${ }^{125}$

As the decree made an unprecedented assertion of Tunisian sovereignty, however, it also compromised that same sovereignty by asserting that some persons, even if born in Tunisia, would not be Tunisian nationals if they were citizens or subjects of France or another European power. This tautological clause - all are Tunisian except those who are not Tunisian- had been painstakingly rewritten. Originally it had referred only to French or foreign "nationality," without any mention of subjecthood. The phrasing was important, for the foreign affairs ministry hoped that "the promulgation of this decree will allow Libyan natives who arrived in Tunisia prior to October 28, 1912,

${ }^{122}$ Décret du 26 redjeb 1332 (June 19, 1914), Journal Officiel, June 20, 1914, 631.

${ }^{123}$ ANT E 504, dr. 13, fol. 4: Telegram, Diplomatie Paris à Résidence Générale, June 6, 1914.

${ }^{124}$ Decreto reggio no. 315, April 6, 1913, Gazzetta Ufficiale Del Regno d'Italia, no. 92 (April 19, 1913), 2278.

${ }^{125}$ French courts in Tunisia made precisely this argument subsequent to the 1914 decree, even ruling in one case that the 1914 decree applied to the estates of persons who died before it went into effect. (Hassen ben Romdan c. héritiers Romdan ben Romdan, Tribunal de Sousse, June 17, 1915, in RAT [1916], pt. 2:40-51. This case drew a long critical commentary from Émile Larcher, who wrote that the court's reasoning could be reduced as follows: "there are false Maltese, therefore all Maltese are false" [43].) See also Salomon U. c. dame U. and David Bonan c. Hamida el Abassi, Cour d'Alger (1ère ch.), February 12, 1918, and Tribunal de 1ère instance de Tunis (1ère ch), December 17, 1917, Arrêt and Jugement, in RAT (1919-20), pt. 2:145-52, including note by Eugène Audinet. 
to be considered Tunisian." 126 "Transitional provisions" established, most importantly, that Libyans in Tunisia would fall under beylical justice for a period of five years while waiting for Italy and France "to conciliate their respective points of view with regard to the matter of principle." ${ }^{127}$ This never happened.

\section{SOVEREIGN TERRITORY?}

Four years and a world war later, France still had not eliminated the problem of extraterritorial sovereignty exercised by its rivals in Tunisia. Maltese, now numbering over 11,000 in the Regency, were exempt from conscription. Italians, invoking the 1896 "most favored nation" accords, managed to avoid paying special taxes imposed on war profits. The impact of this was not negligible since Italian migration to Tunisia had continued to outpace that of the French, and its population there was thus twice as large as France's. ${ }^{128}$ It clearly was not enough to try to end Tunisians' forum shopping by asserting the bey's sovereign right to ascribe Tunisian nationality to persons born in his territory. Protectorate authorities also needed to find a way to make Tunisia's Europeans French. In neighboring Algeria, this had been accomplished in 1889 because the law granting French nationality by virtue of double jus soli-children born in the territory to foreign parents themselves born thereapplied to this "integral" part of France. In Tunisia, however, such an endeavor meant claiming that the French did not merely protect the bey's sovereignty; they also in some ways shared in it.

The effort to have it both ways - to maintain the pretense of the protectorate while claiming territorial sovereignty over Tunisia-engendered a legal sleight of hand in 1921 that first attributed Tunisian nationality to all nonFrench citizens born in Tunisia to parents also born there and then instantaneously "replaced" this Tunisian jus soli nationality with French jus soli nationality for those born to parents who had been subject to French jurisdiction in the protectorate. This was a ruse designed to give an extraterritorial principle some territorial weight. ${ }^{129}$ European powers were not fooled; they

${ }^{126}$ ANT E 504, dr. 13, fol. 4: Telegram, Diplomatie Paris à Résidence Générale, June 6, 1914.

127 ANT E 504, dr. 13: "Dispositions transitoires," signed in Rome, May 29, 1914, art. 3, par. 1 .

${ }^{128}$ For the statistics, see Régence de Tunis, Statistique Générale de la Tunisie, Année 1914, 6. Figures are for the census of 1911. See n. 99 above, on interpreting these statistics. The French government finally gave up trying to dispute the Italian exemption from war-profits taxes in the mid-1920s. See reply to Question Écrite no. 19685, Journal Officiel, Débats de la Chambre (1924), 217.

${ }^{129}$ In two simultaneous decrees, the bey and the French president legislated new nationality policy. Décret du 7 rabia-el-aoual 1340 (November 8, 1921) and Décret du 
recognized a fundamental change to the protectorate settlement when they saw it, which is why France and Great Britain faced off at the International Tribunal in The Hague in 1922. The principal question put to the international court by Great Britain was whether France was entitled to "enact legislation imposing French nationality on British subjects in Tunis as if Tunis were France." 130 The French government's response that "for all those subject to French jurisdiction in Tunisia, the territory of the Regency must be considered to be under French sovereignty" did not win over the tribunal. ${ }^{131}$

France did manage to confer French nationality on children born in Tunisia to Maltese parents themselves born in Tunisia by a law of December 1923, but this came after the court in The Hague had recommended against France, and France had been forced to include a clause in the new law that allowed for these candidates to opt out of French nationality upon reaching adulthood if they so desired. While the British government ceased contesting the policy, clashes with Italians-who were exempt from the 1923 law by virtue of an 1896 treaty-intensified, as the Italians assumed (correctly) that the French government hoped eventually to apply the new nationality policies to them. ${ }^{132}$ Indeed, only a few years later the resident general Lucien Saint concluded that if France hoped to renegotiate the 1896 treaty and thereby subject Italians to "common law," it would have to be willing to link the negotiations to "the entirety of Franco-Italian questions (differences over the Maritime Alps,

8 Novembre 1921, reprinted in Société des Nations-Cour permanente de justice internationale. Contestation élevée par le gouvernement de sa majesté britannique au sujet des décrets de nationalité promulgués à Tunis et au Maroc (zone française) le 8 novembre 1921. Contre-mémoire présenté au nom du gouvernement de la République Français (n.p., 1922) (hereafter Contre-mémoire), 160-61. Replacing the June 19, 1914, decree, the beylical decree of November 8, 1921, held that "all individuals born in the territory of our realm to parents one of whom was also born in the territory" are Tunisian, unless they are "citizens, subjects, or nationals of the protecting power." Gone was any reference to "foreign" citizens or subjects. The presidential decree, meanwhile, declared French any individual born in the Regency of Tunis who had one parent also born there, provided that the parent had, by virtue of foreign status, been subject to French jurisdiction in the protectorate. For discussion of why this ruse was necessary, see AMAE, CPC, Tunisie 1917-40, dr. 170-1, fol. 15ff.: Minute, Afrique, June 10, 1921, au sujet des Anglo-Maltais de Tunisie et d'une façon plus générale, des individus d'origine européenne nés dans la Régence.

${ }^{130}$ Nationality decrees. Tunisia and Morocco (French Zone). Question submitted to the Permanent Court of International Justice. Case presented on behalf of the Government of His Britannic Majesty to the Permanent Court of International Justice (November 25, 1922) (n.p., n.d.), 15.

131 Contre-mémoire, 9.

${ }^{132}$ Multiple reports in AMAE, CPC, Tunisie 1917-40, drs. 176, 177, 178; see also Shorrock, "Tunisian Question," 637. 
Tangier, Abyssinia, Syria, etc.)." ${ }^{133}$ This was important because France might someday "find itself obliged, against its will [à son corps défendant], to annex the Regency," in which case "Italy must not be able to intervene and demand concessions or impose its veto. The potential annexation of Tunisia must not spark resistance analogous to that encountered by Austria at the time of its annexation [in 1908] of Bosnia-Herzegovina." To secure Italy's quiescence in the event of annexation, Saint proposed a secret protocol. ${ }^{134}$ France did not, of course, annex Tunisia, but the fact that officials in Tunisia even entertained the idea shows their frustration with the limits of the protectorate compromise.

In the end, France only succeeded in applying jus soli nationality to Tunisia-born Italians when Pierre Laval and Benito Mussolini agreed on a phase in of French nationality. The resulting treaty and special protocol of January 7, 1935, projected France's presence in Tunisia forward some thirty years. It held that children born in Tunisia to Italian parents before March 1945 would remain Italian, children born between March 1945 and March 1965 would have the option of claiming French nationality in the year following their majority, and children born after March 1965 would be considered French nationals definitively. ${ }^{135}$ Clearly, no one yet predicted that Tunisia would become independent in 1956. Although Laval denied any quid pro quo associated with the agreements, it is well established that he secured them by secretly promising Mussolini that France would not protest Italian intervention in Ethiopia. ${ }^{136}$

The case at The Hague in 1922, the Rome Accords of 1935, and other such renegotiations of the protectorate settlement between France and powers active in the Mediterranean demonstrated that, well into the twentieth century, France still struggled to end the extraterritorial sovereignty that foreign governments exercised in small ways every day in Tunisia. This ongoing contest had constantly exposed the fault lines in the protectorate compromise, as it

${ }^{133}$ AMAE, CPC, Tunisie 1917-40, dossier 178, fols. 29-60: Memorandum sur la substitution du droit commun au régime de privilèges institué en faveur des Italiens en Tunisie par les Conventions de 1896, September 15, 1926, signed Lucien SAINT.

134 Ibid.

135 Accords de Rome: Traité entre la France et l'Italie concernant l'établissement de leurs intérêts en Afrique (January 7, 1935) and Protocole spécial concernant les questions tunisiennes (January 7, 1935), in Charles-André Julien, La Question Italienne en Tunisie 1868-1938, preface by Yvon Delbos (Paris, 1939), apps. 19 and 20.

${ }^{136}$ For Laval's denial, see Journal Officiel, Débats de la Chambre (December 28, 1935), 2863-65. That the Italians understood him as granting them free rein in East Africa is evident from the following exchange of letters: Count Ciano, Italian Minister of Foreign Affairs, to François Poncet, French Ambassador in Rome, December 17, 1938; and Poncet to Ciano, December 25, 1938, in Julien, La Question, apps. 22 and 23. For discussion of the secret protocols, see Shorrock, "Tunisian Question." For Italy's approach to Tunisia during the Mussolini regime, see esp. Bessis, Méditerranée fasciste. 
facilitated boundary crossings that were both physical—across the borders of various Mediterranean territories—and legal, from "native" to "European," from subjected to protected. Tunisian subjects' willingness to traverse these boundaries in advancing their own claims not only perpetuated this international rivalry but also forced changes in the domestic civic order.

The story told here thus compels a rethinking of the narrative of imperial history in Africa. It suggests that the "scramble" among European powers for empire never really ended and that the shape this competition took depended on how European governments continued to broker influence in lands claimed by their rivals, as well as the ways in which locals exploited the divisions between those powers. Seen from this vantage point, 1881 did not mark the end of intra-European struggle for influence in Tunisia, nor did the bey's capitulation to France's ultimatum signal the acquiescence of Tunisians to a rigid civic order that entirely foreclosed their ability to make demands on the colonial state. Rather, for the first half century of the protectorate's existence, French leaders perpetually scrambled to buttress their authority in Tunisia against the dual and compounding threats of individuals' jurisdictional maneuvering on the local level and rival states' efforts to gain influence in North Africa. For the remaining quarter century of the protectorate, the French faced a different sort of problem: anticolonial nationalism, a rights movement premised no longer on maximizing Tunisians' interests within the framework of mixed sovereignty but on challenging the very basis of the protectorate premise. 